\title{
Skeptical Scrutiny Of Plenary Power: Judicial and Executive Branch Decision Making in Miller v Albright
}

Cornelia T. Pillard

Georgetown University Law Center, pillardn@law.georgetown.edu

T. Alexander Aleinikoff

This paper can be downloaded free of charge from:

https://scholarship.law.georgetown.edu/facpub/721

1 Sup. Ct. Rev. 1-70 (1998)

This open-access article is brought to you by the Georgetown Law Library. Posted with permission of the author. Follow this and additional works at: https://scholarship.law.georgetown.edu/facpub

Part of the Civil Rights and Discrimination Commons, Constitutional Law Commons, Immigration Law Commons, and the Military, War, and Peace Commons 
In 1996, just a few months after the United States successfully urged the Supreme Court in United States $v$ Virginia ${ }^{1}$ to invalidate as sex-discriminatory the male-only admissions policy at the Virginia Military Institute, the District of Columbia Circuit in Miller $v$ Albrigbt ${ }^{2}$ upheld a federal law that used an express, sex-based

Cornelia Pillard is Associate Professor of Law, Georgetown University Law Center. She is currently on leave to work in the U.S. Department of Justice as Deputy Assistant Attorney General, Office of Legal Counsel. T. Alexander Aleinikoff is Professor of Law, Georgetown University Law Center.

Authors' note: We would like to thank Catherine W. Brown, David D. Cole, Walter E. Dellinger III, Edward C. DuMont, Vicki C. Jackson, Edwin S. Kneedler, Martin S. Lederman, David A. Martin, Hiroshi Motomura, Gerald L. Neuman, Donald Patterson, Louis H. Pollak, Susan Deller Ross, Peter H. Schuck, Louis Michael Seidman, Peter J. Spiro, Mark V. Tushnet, Carlos M. Vázquez, and Robin L. West and members of the Georgetown University Law Center faculty workshop for their thoughtful comments regarding earlier drafts of this article. Special thanks also to the Law Center for providing us with summer writing grants, and for enabling us to hire Keri McGrath and Daniel Wadleigh to provide their excellent research assistance. Professor Aleinikoff was General Counsel and Executive Associate Commissioner at the Immigration and Naturalization Service from 1994 to 1997; Professor Pillard was an Assistant to the Solicitor General from 1994 to 1997, where she drafted briefs for the United States in United States v Virginia. The views expressed herein are the authors' own views, however, and, except where specifically so stated, should not be understood to express the views of the United States or of any of the persons thanked herein.

1518 US 515 (1996).

${ }^{2} 118$ S Ct 1428 (1998).

(C) 1999 by The University of Chicago. All rights reserved.

0-226-36316-3/99/1998-0005\$02.00 
distinction. Section 309(a) of the Immigration and Nationality Act (INA) makes it harder for male U.S. citizens than for female citizens to convey their citizenship to their children if those children were born abroad out of wedlock and the other parent was not a U.S. citizen. ${ }^{3}$ Notwithstanding the United States' position in Virginia that sex-based classifications are virtually always unconstitutional, the government defended Section 309(a) in the Supreme Court. As the government saw it, Miller involved a claim by an alien abroad, so the Constitution did not apply or, at most, the Court should review the claim with extraordinary deference to the political branches. If deferential review applied, rather than Virginia's "skeptical scrutiny," the government believed that the Court should uphold the statute.

When review was granted, the case seemed to present an opportunity for the Court to revisit the larger issue it had addressed two decades earlier in Fiallo $v$ Bell: ${ }^{4}$ how to reconcile heightened, "skeptical" scrutiny of sex-based classifications with diminished scrutiny of immigration and naturalization measures in a case that seemed to call for both. The Court in Fiallo had sustained a sexbased classification in an INA provision closely analogous to Section 309(a), but dealing with eligibility for permanent resident status rather than citizenship. Fiallo treated Congress's plenary power over immigration as categorically trumping the otherwise heightened level of scrutiny applicable to sex-based classifications. But virtually the entire body of modern constitutional law on sex discrimination developed after Fiallo. The Court decided Fiallo in 1977, close on the heels of its 1976 decision in Craig $v$ Boren, ${ }^{5}$ the first case in which it applied intermediate constitutional scrutiny to a sex-based classification. The two ensuing decades of sex discrimination decisions strengthened and clarified the equal protection standard. The court of appeals in Miller had upheld the statute under Fiallo over a dissent arguing that the Supreme Court should reconsider Fiallo in light of the intervening sex discrimination jurisprudence. The government's brief in opposition to certiorari characterized Miller as squarely governed by Fiallo, so the Supreme

\footnotetext{
${ }^{3} 8$ USC $\$ 1409$ (a).

${ }^{4} 430$ US 787 (1977).

${ }^{5} 429$ US 190 (1976).
} 
Court's decision to grant review so soon after Virginia suggested that Fiallo might be headed for the dustbin.

Instead, the Court issued a decision on nonjusticiability grounds that was so fractured and narrow as to seem almost meaningless. But there is, on closer examination, much that is surprising and significant about Miller. The case provides an opportunity for reexamining the nature and justifications for the plenary power doctrine.

We start by analyzing Section 309(a) and explaining why we believe those Justices who concluded that the statute unconstitutionally discriminates based on sex are clearly right. We then argue that judicial deference under the plenary power doctrine is an institutionally rather than substantively based doctrine-meaning, not that sex discrimination is more tolerable in immigration and naturalization than it is domestically, but that sex discrimination norms are judicially underenforced in the former context for reasons relating to the relative institutional competence of the judiciary and the political branches.

We then look at Miller's implications for the future of the plenary power doctrine. Although the Court did not reach the merits, the five separate opinions provide significant clues about the current Justices' thinking on the interplay between plenary power and constitutional rights. A majority of the Justices distinguished Ms. Miller's claim from the immigration claims in Fiallo by emphasizing that Miller sought not immigration but citizenship, and suggested that the Court would fully enforce equal protection norms in a citizenship case. The Justices' disinclination to apply plenary power deference to citizenship claims is supported by the importance of citizenship to the individual who claims it, as well as by the lack of persuasive justifications for allowing discriminations against putative citizens abroad that we do not tolerate in the domestic context. Ultimately, however, we show why we do not think that the Court can draw a stable distinction between a claim of jus sanguinis (bloodline) citizenship such as Ms. Miller's and an immigration or naturalization claim. Miller raises the prospect that the plenary power doctrine is as inappropriate in immigration and nationality law generally as the Justices in Miller suggest it is for jus sanguinis citizenship claims.

Finally, we discuss the implications for government lawyers of our sex discrimination and plenary power analyses. That discussion 
has two parts: First, we argue that the underenforced-norms reading of the plenary power cases suggests that the political branches should not use deferential, rational-basis review in conducting their own constitutional review of immigration, nationality, or citizenship measures, but should apply full-fledged constitutional norms. Second, we argue that, after Miller, the courts lack adequate justifications for the plenary power doctrine-at least in the absence of a new, substantive rationale for diminished protection of individual rights-in jus sanguinis citizenship cases like Miller, and, indeed, lack grounds for relying on it in immigration and nationality cases generally.

\section{Section 309(a) AND the Miller Litigation}

There are few sex-based classifications left in federal law, apart from a handful in military statutes ${ }^{6}$ and a few in laws governing immigration, naturalization, and bloodline citizenship. Section 309 (a) of the INA is one of these increasingly rare laws. Under Section 301(g) of the INA, a child who is born abroad of one alien parent and one U.S. citizen parent is generally deemed to be a citizen of the United States at birth.' But if such a child was born out of wedlock and the citizen parent is the father, Section 309(a) imposes several additional conditions, including: that a blood relationship between the child and the father be established by clear and convincing evidence; that the father have agreed in writing to provide financial support for the child until she or he turns eighteen; and that, while the child is under the age of eighteen, the father legitimate the child or acknowledge paternity in writing under oath, or that paternity be established by adjudication. ${ }^{8} \mathrm{~A}$

\footnotetext{
${ }^{6}$ The Military Selective Service Act, providing for a male-only draft, was upheld against an equal protection challenge in Rostker $\dot{v}$ Goldberg, 453 US 57 (1981). The Act has since been repealed.

'Immigration and Nationality Act ("INA") $§ 301(\mathrm{~g}), 8$ USC $\$ 1401$ (g).

${ }^{8}$ INA $\$ 309(a), 8$ USC $\$ 1409$ (a), provides:

The provisions of paragraphs (c), (d), (e), and (g) of Section 1401 of this title, and of paragraph (2) of Section 1408 of this title lestablishing U.S. citizenship or nationality of certain children born abroad], shall apply as of the date of birth to a person born out of wedlock if-

(1) a blood relationship between the person and the father is established by clear and convincing evidence,

(2) the father had the nationality of the United States at the time of the person's birth,
} 
child born out of wedlock to a U.S. citizen mother is not subject to Section 309(a) but instead "shall be held to have acquired at birth the nationality status of his mother." In other words, an unmarried citizen mother's citizenship passes virtually automatically, ${ }^{10}$ whereas an unmarried citizen father must not only prove the parental link that for the mother is assumed, but must also meet a deadline for establishing a formal legal relationship with his child and agree to support her financially until she reaches age eighteen. ${ }^{11}$

There is an additional sex-based distinction in the duration of U.S. residency required of parents wishing to convey citizenship to their nonmarital children born abroad. The citizen parent in a mixed-citizenship couple-whether married or not-generally must have been a U.S. resident for at least five years before the child's birth in order to convey citizenship to that child. ${ }^{12}$ Citizen mothers of nonmarital children, however, need only have resided in the United States for one year in order to convey citizenship. ${ }^{13}$ Congress added the shorter, one-year residency requirement in 1952, apparently based on a concern to avoid statelessness on the part of nonmarital children of U.S. citizen mothers. ${ }^{14}$ The assump-

(3) the father (unless deceased) has agreed in writing to provide financial support for the person until the person reaches the age of 18 years, and

(4) while the person is under the age of 18 years-

(A) the person is legitimated under the law of the person's residence or domicile,

(B) the father acknowledges paternity of the person in writing under oath,

or court.

(C) the paternity of the person is established by adjudication of a competent

${ }^{9}$ INA $\$ 309$ (c), 8 USC 1409(c).

${ }^{10}$ But see 7 US Dep't of State, Foreign Affairs Manual 1131.4, 1131.5-4(b)-(c), 1133.6 (rev 2/15/91) (requiring some evidence of maternity).

${ }^{11}$ Under a transitional provision applicahle to Lorelyn Miller, she had the option to elect a deadline of her twenty-first, not eighteenth, birthday. See note following 8 USC $\$ 1409$ (effective date of 1986 antendment); 118 S Ct 1428, 1433 n 3 (Stevens opinion). Ms. Miller's application was untimely under either deadline, however, and for sinıplicity we will refer to the age-eighteen deadline.

${ }^{12}$ The citizen parent must have, before the child's birth, been "physically present in the United States or its outlying possessions for a period or periods totaling not less than five years, at least two of which were after attaining the age of fourteen years," with overseas service in the U.S. military or with certain international organizations counting toward the residency requirement. INA $\$ 301(\mathrm{~g}), 8$ USC $\$ 1401(\mathrm{~g})$.

${ }^{13}$ INA $\$ 309$ (c), 8 USC $\$ 1409$ (c).

${ }^{1+}$ The Senate Report describes the purpose of the new, shorter residency requirentent for mothers as "insur[ing] that the child shall have a nationality at birth." $\mathrm{S}$ Rep No 1137, 82d Cong, 2d Sess 4 (Jan 29, 1952). 
tion behind that concern seems to have been that other countries generally granted citizenship to nonmarital children only through their mothers, potentially leaving nonmarital children born overseas of foreign fathers and U.S. mothers without any nationality at all. ${ }^{15}$

Lorelyn Penero Miller was born in the Philippines in 1970 to Luz Penero, a Filipina, and Charlie Miller, a U.S. soldier stationed in the Philippines. Mr. Miller and Ms. Penero were unmarried. Mr. Miller returned to the United States when his tour of duty ended. He apparently was not much of a letter writer, but as Ms. Miller grew up she corresponded regularly with her paternal grandmother who lived near Mr. Miller in Texas. After her grandmother died some time in the late 1980s, Ms. Miller had more frequent direct communication with her father. Neither of them was aware, however, of the deadline in Section 309(a) for establishing the prerequisites for Ms. Miller's birthright citizenship. As it happened, it was not until shortly after Ms. Miller's twenty-first birthday that her father got a voluntary paternity decree from a Texas court, and Ms. Miller applied for recognition as a U.S. citizen. The State Department rejected the application on the ground that Ms. Miller's father had not formally legitimated her and agreed to provide her financial support before she came of age. ${ }^{16}$ Ms. Miller brought suit challenging the constitutionality of Section 309(a), and her father joined as a plaintiff.

Both lower courts upheld the statute. The district court held

\footnotetext{
${ }^{15}$ The differential residency requirements were not at issue in Miller, hecause Mr. Miller satisfied the more stringent requirements applicable to citizen fathers. See Miller $v$ Albright, $118 \mathrm{~S} \mathrm{Ct}$ at 1435 \& nn 5-8 (Stevens opinion). The requirement that a blood relationship between the child and the father, but not the mother, be proved by clear and convincing evidence was also not at issue, because the government conceded that petitioner met it. See id at 1436. As for the requirement that the father, but not the mother, agree in writing to provide financial support for the child until she reaches age eighteen, Justice Stevens stated that it was "unclear" whether that provision even applied to petitioner's case in view of her eligibility for an interim provision not applying that requirement, and the State Department's apparent reliance only on Section 309(a)(4) to deny Ms. Miller citizenship. Id at 1436. The focus in Miller was thus on the age-eighteen deadline for legally estahlishing paternity.

${ }^{16}$ Interestingly, it was not at first clear that the statute would be enforced. When Lorelyn Miller initially submitted the Texas court's voluntary paternity decree to the U.S. Emhassy in Manila, consular officials responded that "in our opinion, the petition decree legitimizes Lorelyn at birth." See Br for Pet 5. Moreover, at that time a federal court in New Jersey had held that Section 309 unconstitutionally discriminates against illegitimate children, and the governinent apparently declined to appeal. LeBrun v Thormburgh, 777 F Supp 1204, 1210-14 (D NJ 1991).
} 
that Fiallo barred the equal protection claims and that Ms. Miller lacked a redressable injury because, under INS $v$ Pangilinan, ${ }^{17}$ the courts lack power to grant citizenship as a remedy. ${ }^{18}$ The court of appeals disagreed that Ms. Miller's injury was judicially nonredressable, but held that, under the deferential standard of review applicable to "rules for the admission and exclusion of aliens," the statute withstood constitutional challenge. The court concluded that the statute rationally served an interest in promoting early ties to the United States and to the citizen parent: "A mother is far less likely to ignore the child she has carried in her womb than is the natural father, who may not even be aware of its existence," and it is therefore "entirely reasonable for Congress to require special evidence of such ties between an illegitimate child and its father." 19 Judge Wald concurred in the judgment because she believed Ms. Miller's claim was foreclosed by Fiallo, but she asserted that Fiallo is "out of step" with current law and "should be changed by Congress or the Supreme Court." 20

\section{A. THE GOVERNMENT'S POSITION}

The Supreme Court granted Ms. Miller's petition seeking review of the question whether Section 309(a) unconstitutionally discriminates based on sex. ${ }^{21}$ Somewhat surprisingly, in view of the United States' recent successful argument in Virginia that even largely accurate sex-based generalizations virtually always violate equal protection, the government argued in the strongest terms

${ }^{17} 486$ US 875 (1988) (holding, in response to equal protection and due process challenge, that courts lack power to confer citizenship on group of veterans under long-expired special immigration statute authorizing citizenship by naturalization on Filipino nationals who served with the U.S. Armed Forces during World War II).

${ }^{18}$ Miller v Christopher, Civ 6:93CV39 (ED Tex June 2, 1993) (reprinted in App B to Br for Resp Miller $v$ Albright, 118 S Ct 1428 (1998) (No. 96-I060)), and 870 F Supp 1, 3 (DDC 1994).

${ }^{19}$ Miller v Christopher, 96 F3d 1467, 1472 (DC Cir 1996).

${ }^{20}$ Id at 1477.

${ }^{21}$ The question presented was "is the distinction in 8 USC $\$ 1409$ between 'illegitimate' children of US citizen mothers and 'illegitimate' children of U.S. fathers a violation of the Fifth Amendment to the Umied States Constitution." See Miller v Albright, 117 S Ct 1689 (1977) (Mem). The Court amended the grant of certiorari to limit its consideration to that question from among the five that the petitioner presented, which included questions whether the statute unconstitutionally discriminates based on illegitimacy, and whether the Court should give effect to the retroactivity of the state court's paternity determination. Compare id with Pet 1. 
that sex-based classifications relating to immigration and nationality should be subject to little or no judicial review. ${ }^{22}$ The government argued that Fiallo controlled, and that because Congress has "plenary power" over immigration and nationality, the Court should review Section 309(a)'s sex-based distinctions with "extraordinary deference," and should uphold the statute "so long as it was based on a facially legitimate and bona fide reason"-a standard the government described as "more deferential even than the familiar 'rational basis' standard applied in the context of purely domestic legislation." 23 Such deference, the government insisted, "is not a relic of the legal past," but rests on the Constitution's delegation to Congress of power over naturalization, as well as on considerations of "national sovereignty, foreign relations, and the fundamentally political character of immigration and nationality decisions." 24 Those considerations, it maintained, place claims such as Ms. Miller's "beyond the institutional competence of the judiciary." 25 The government also asserted that Ms. Miller, as an alien outside the United States, had no substantive rights under the Fifth Amendment. ${ }^{26}$ Insofar as the rights of Mr. Miller, a U.S. citizen, might be implicated, it contended that the Court should also review his equal protection claim with the kind of deference ordinarily reserved for immigration matters, because full-fledged constitutional review of a citizen parent's claim "would vitiate the rule of deference in the context of acquisition of nationality through birth abroad." 27

The government did not, however, rest entirely on the deferential standard of review. It also argued that Section 309(a) should be sustained even if subjected to heightened scrutiny under United States $v$ Virginia. ${ }^{28}$ Section 309(a)'s different treatment of unmar-

\footnotetext{
${ }^{22}$ The government also contended that, as a threshold matter, there was no justiciable issue presented because Mr. Miller lacked standing. Br for Resp 10-12.

${ }^{23} 1 \mathrm{~d}$ at 8-9, 21 (quoting Fiallo, 430 US at 792), 34 \& n 19.

${ }^{24}$ Id at 8, 12-14, 22.

${ }^{25}$ Id at 22.

${ }^{26}$ Id at $10-12$.

${ }^{27}$ Id at $38 \mathrm{n} 20$. See also id at 42 ("whatever a citizen's interest in the matter, the actual subject of an immigration or naturalization law like that at issue here is the alien abroad, who has no right to invoke the heightened scrutiny of gender-based distinctions that is required in other contexts by the United States Constitution.").

${ }^{28}$ Id at 43 n 22.
} 
ried citizen fathers of foreign-born children as compared with mothers was, in the government's view, "not based on invidious gender stereotypes, but on real differences" in the situation of the citizen mothers and putative citizen fathers of illegitimate children born abroad. ${ }^{29}$ The government argued that the statutory requirements of legally establishing paternity and providing financial support tie the child to the United States by ensuring that the child has a "nexus to a citizen parent." 30 The mother physically bears the child, her maternal relationship typically is legally established immediately by the birth certificate, and her financial support obligations flow from that legal relationship. The government thus characterized Sections 309(a)(3) and (4) as placing the out-ofwedlock child of a U.S. citizen father "in a position roughly equivalent to that of the typical foreign-born child claiming through an unmarried citizen mother." 31 The government acknowledged that Section 309(a)(4)'s time deadline on proof of paternity cannot be explained as serving the need for reliable proof of a blood relationship in view of the separate provision requiring clear and convincing proof of paternity, ${ }^{32}$ but speculated that the animating concern might have been to ensure "that citizenship not devolve automatically on a foreign-born child who is unlikely to develop, in his or her formative years, substantial personal ties to the United States." 33

\section{B. THE COURT'S DECISION}

As framed, the case seemed poised either to reaffirm the deferential plenary power standard applied in Fiallo or to strike down the statute based on post-Fiallo developments in sex discrimination law. The Court did neither, although, as we explain, it did lay important groundwork for the latter course.

A fractured Court upheld the statute. Justice Stevens rejected the sex discrimination claim on its merits, but his opinion garnered

\footnotetext{
${ }^{29}$ Id at 43 .

${ }^{30} \mathrm{Id}$ at $24,26$.

${ }^{31}$ Id at 24.

${ }^{32}$ 'The government's brief pointed out that Congress in 1986 revised the statute to require clear and convincing proof of biological paternity without imposing any time limitation, and the State Department "has never declined to recognize such testing," so long as reliably performed. Id at 27.

${ }^{33} \mathrm{Id}$ at $27-28$.
} 
only the additional vote of Chief Justice Rehnquist, with four other Justices concurring in the judgment on other grounds. ${ }^{34}$ The concurring Justices concluded either that Ms. Miller had no first-party claim and lacked third-party standing to raise her father's claim, ${ }^{35}$ or that her injury was not judicially redressable in view of courts' lack of power to confer citizenship as a remedy. ${ }^{36}$

Miller is a peculiar decision because, although the government prevailed, the Court upheld the statute in only the most formal sense, and none of the government's arguments persuaded a majority of the Court. The Court did not validate the statute's constitutionality; in fact, Justice Ginsburg asserted in her dissenting opinion that "a solid majority" of the Court-Justices O'Connor and Kennedy and the three dissenters-believed Section 309(a) unconstitutionally discriminates on the basis of sex. ${ }^{37}$ That may be an overstatement in view of Justice O'Connor's limited opinion. ${ }^{38}$ But it is certainly accurate that no majority endorsed the statute's constitutionality as a matter of equal protection. There was also no majority for the government's proposition that a deferential standard of review should apply to Ms. Miller's claim; the five Justices who analyzed her claim on the merits at all applied heightened review in light of Ms. Miller's asserted right to citizenship from birth. ${ }^{39}$ Not a single Justice embraced the government's suggestion that Ms. Miller was an alien lacking any Fifth Amendment rights. ${ }^{40}$ At least where a person outside the United States raises a citizenship claim, as Ms. Miller did, a majority of the Justices viewed her as a rights holder under the Constitution. ${ }^{41}$ And the

\footnotetext{
${ }^{34} 118 \mathrm{~S} \mathrm{Ct}$ at 1432-42 (Stevens opinion, joined by Rehnquist); id at 1442-46 (O'Connor, joined by Kennedy, concurring); id at 1446-49 (Scalia, joined by Thomas, concurring).

${ }^{35}$ Id at 1442 (O'Connor, joined by Kennedy, concurring).

${ }^{36}$ Id at 1446 (Scalia, joined by Thomas, concurring).

${ }^{37} \mathrm{Id}$ at 1450 (Ginsburg, joined by Souter and Breyer, dissenting).

${ }^{38}$ See text at note 65. Although Justices O'Connor and Kennedy stated that Section 309(a) could not withstand heightened scrutiny, it remains an open question whether they would apply heightened scrutiny or some lower level of review had they believed that the claim of sex discrimination in birthright citizenship was properly before the Court.

${ }^{39} 18 \mathrm{~S} \mathrm{Ct}$ at 1436-42 \& n 11 (Stevens opinion); id at 1458-63 (Breyer opinion).

${ }^{40} \mathrm{Id}$ at $1436 \mathrm{n} 10$ (Stevens opinion); id at 1445 (O'Connor concurring); id at 1456-57 (Breyer dissenting); see also id at $1447 \mathrm{n} 1$ (Scalia concurring).

${ }^{41}$ Seven Justices distinguished Jobnson v Eisentrager, 339 US 763 (1950), and United States $v$ Verdugo-Urquidez, 494 US 259 (1990) - cases in which the Court had held that aliens abroad lacked constitutional rights-as not involving persons abroad claiming U.S. citizenship or nationality. Id at 1436 n 10 (Stevens opinion); id at 1456-57 (Breyer dissenting)
} 
Justices also rebuffed the government's contention that, in the realm of immigration and naturalization, courts should review the constitutional claims of even established citizens such as Charlie Miller with extra deference to the political branches; ${ }^{42}$ five Justices applied heightened scrutiny to Ms. Miller's third-party claim that the statute unconstitutionally discriminates between U.S. citizen fathers and their U.S. citizen mother counterparts. ${ }^{43}$

1. Miller as a justiciability decision. The Miller decision seems anticlimactic at first blush. As noted above, the Court appeared to have granted review to revisit the plenary power doctrine as it affects sex discrimination claims, and perhaps to overrule or limit Fiallo. But, as it turned out, the dispositive votes were cast on nonjusticiability grounds, with Justices O'Connor and Kennedy voting to affirm based on a perceived lack of third-party standing, and Justices Scalia and Thomas on the ground that petitioner's injury was not judicially redressable. Neither of those issues had been raised in the government's brief in opposition to the petition for certiorari, and their resolution had not seemed to be the focus of the case when the Court agreed to hear it. ${ }^{44}$

The standing question had a convoluted history in the litigation. On the government's motion, the district court had held that Mr. Miller lacked standing to challenge Section 309(a) because it was his daughter, not he, who suffered the harm of citizenship denial. ${ }^{45}$

("those cases [Eisentrager and Verdugo-Urquidez], as Justice Stevens points out, are irrelevant, for the matter at issue here is whether or not Lorelyn is a citizen."); id at 1445 (O'Connor concurring) ("[w]hile it is unclear whether an alien may assert constitutional ohjections when he or she is outside the territory of the United States [citing Eisentrager and Verdugo-Urquidez], I will assume that petitioner may challenge the constitutionality of $\left.\$ 1409^{\prime \prime}\right)$.

Because Justice Scalia concluded that Ms. Miller had standing to raise her father's claim, he found that "there is no need for me to reach the Government's claim . . . that petitioner cannot invoke the Equal Protection Clause on her own behalf because she is not within the jurisdiction of the United States." Id at 1447 n 1 (Scalia concurring).

${ }^{42} \mathrm{Br}$ for Resp 38 n $20,42$.

${ }^{43} 118 \mathrm{~S} \mathrm{Ct}$ at 1437-42 (Stevens opinion) (analyzing statute under heightened scrutiny); id at 1454 (Ginsburg, joined hy Souter and Breyer, dissenting); id at 1457-58 (Breyer, joined by Souter and Ginsburg, dissenting).

${ }^{44}$ Indeed, the government at the petition stage apparently took the opposite view of the redressability issue from the one it (and Justices Scalia and Thomas) ended up adopting. In its Brief in Opposition, the government stated that "the court of appeals correctly concluded that petitioner could be declared a citizen by virtue of the general rule of section $1408(\mathrm{~g})$. . . if [the Court] declared the specific rule of Section 1409(a) unconstitutional." $\mathrm{Br}$ in Opp 13-14.

${ }^{45}$ See $118 \mathrm{~S}$ Ct at 1433. 
With Mr. Miller, a Texas resident, out of the case, the federal court in Texas transferred it to the U.S. District Court for the District of Columbia. Mr. Miller did not appeal his dismissal, ${ }^{46}$ and the case proceeded with Ms. Miller as the sole plaintiff. Once Charlie Miller was out of the case, however, the government argued to the Supreme Court that the district court had it backwards: It was Charlie Miller, and not his daughter, who had been the victim of discrimination, and she lacked third-party standing to raise his claim.

Only Justices O'Connor and Kennedy agreed, but they provided crucial swing votes. Justice O'Connor observed that Section 309 "accords differential treatment to fathers and mothers, not to sons and daughters." 47 Petitioner thus was not herself a victim of sex discrimination; the only sex discrimination claim at issue was the father's claim that he should have the same right as a citizen mother to convey U.S. citizenship to his child. ${ }^{48}$ In holding that Ms. Miller lacked standing, Justice O'Connor stressed that thirdparty standing is "a prudential limitation on the exercise of federal jurisdiction," under which a party injured by a statute may challenge it on behalf of a person to whom she has a close relation only if there is "some hindrance to the third party's ability to protect his or her own interests." ${ }^{49}$ Ms. Miller concededly had both a close relation to her father (at least in the abstract) and an injury, but Justice O'Connor did not view the government's erroneous yet successful motion in the district court to dismiss Mr. Miller from the case, nor the transfer of the case away from his home state of Texas to Washington, D.C., as sufficient hindrance to justify thirdparty standing. ${ }^{50}$ As a practical matter, Justice O'Connor's standing

\footnotetext{
to The appeal would have required the plaintiffs to litigate on two fronts-in the Fifth Circuit on Mr. Miller's appeal, and in the DC Circuit on Ms. Miller's appeal. Moreover, the plaintiffs' lawyer believed that Ms. Miller's claim was the heart of the case, and that in any event her third-party standing was clear under Wauchope $v$ United States Department. of State, 985 F2d 1407, 1410-11 (9th Cir 1992). August 27, 1998, telephone conversation with the Millers' counsel, Donald Patterson.

${ }^{47} 118 \mathrm{~S} \mathrm{Ct}$ at 1442.

${ }^{48} \mathrm{Id}$.

${ }^{49}$ Id at 1443 (quoting Powers $v$ Obio, 499 US 400, 411 (1991)).

${ }^{50}$ Id at 1443-45. Notwithstanding that Mr. Miller had been a co-plaintiff, Justice O'Connor believed that the fact that he "never indicated any intent to challenge his dismissal from the suit" suggested a lack of interest in enforcing his rights. In Justice O'Connor's view, "any hindrance to the vindication of Charlie Miller's constitutional rights is ultimately self inposed." Id at 1444.
} 
decision was necessary to the outcome, but as a precedential matter, it lacks force because seven Justices-including four who supported the judgment-disagreed with it. ${ }^{51}$

Thus, a majority of the Justices believed that Ms. Miller had third-party standing to raise her father's claims, and a majority also appears to have thought that Section 309(a) unconstitutionally discriminated against Mr. Miller. Section 309(a) survived at least in part because those views were held by different majorities. But Miller placed Section 309(a) on the chopping block. When the right plaintiff comes along, the relevant guidance for the lower courts comes not from the standing analysis, but from the majority of the Justices' views on the merits. ${ }^{52}$

As Justice Scalia pointed out, however, there is another potential justiciability obstacle that the lower courts will have to contend with before ruling for the next citizen-father who sues: whether the courts can redress the injury by granting citizenship to the plaintiff's child. ${ }^{53}$ It remains unclear under Miller how real that second obstacle is. The three dissenting Justices expressly disagreed with Justice Scalia that any such bar existed, ${ }^{54}$ but the four other Justices did not state their views. ${ }^{55}$

Justice Scalia, joined by Justice Thomas, started from the prem-

\footnotetext{
${ }^{51}$ Five of the Justices-Stevens, Souter, Ginsburg, Breyer, and Chief Justice Rehnquistconcluded that Ms. Miller had standing to raise claims on her own behalf as well as thirdparty standing to assert her father's claim. Id at 1436 (Stevens opinion) (agreeing with the court of appeals' holding as to Ms. Miller's own standing, and holding under Craig v Boren, 429 US 190 (1976), that she could raise her father's claims of discrimination); id at 145657 (Breyer dissenting) (finding third-party standing on the ground that "the conclusion that the Government 'hindered' Charlie's assertion of his own rights in this case is irresistible," and opining that Ms. Miller had a first-party discrimination claim because "she belongs to a class of children of citizen-fathers, whom the law distinguishes from the class of children of citizen-mothers, solely on the ground of the parent's gender"). Justice Scalia, joined by Justice Thomas, "accept[ed] petitioner's third-party standing." Id at $1447 \mathrm{n} 1$.

${ }^{52}$ The propriety of lower court judges counting the Justices' votes-rather than limiting consideration to what Professor Caminker has called "unified-majority dispositional rules"-is debatable, but a strong case can be made in favor of judges considering the Court's "fragmented-majority dispositional rules" such as those in the Miller opinions. See Evan H. Caminker, Precedent and Prediction: The Forward-Looking Aspects of Inferior Count Decisionmaking, 73 Tex L Rev 1 (1994).

${ }^{53} 118 \mathrm{~S} \mathrm{Ct}$ at $1446-50$.

${ }^{54}$ Id at $1463-64$ (Breyer dissenting).

${ }^{55}$ See id at 1442 (Stevens opinion) ("Because we conclude that there is no constitutional violation to remedy, we express no opinion on this question"); id at 1445 (O'Connor concurring) (referring to "the potential problems with fashioning a remedy for [petitioner's] injury" as a factor weighing against recognition of petitioner's third-party standing).
} 
ise that the Constitution confers birthright citizenship only on persons born in the United States, and that for all others Congress controls the terms of naturalization: "If there is no congressional enactment granting petitioner citizenship, she remains an alien." 56 Ms. Miller acknowledged that she could not meet two statutory preconditions to the acquisition of citizenship-the requirements that (1) her father commit in writing to support her until she reached legal majority, ${ }^{57}$ and (2) she be legitimated, or that her father's paternity be adjudicated or acknowledged, before she reached age eighteen. ${ }^{58}$ In Justice Scalia's view, that failure ended the matter, because the Court lacked authority to sever the allegedly unconstitutional provisions and grant her citizenship under the remaining statutory terms.

Justices Breyer, Souter, and Ginsburg disagreed; in their view, the Court could remedy the discrimination by striking from the statute the offending provisions. The Court need not grant citizenship, the dissenters asserted, because without the sex-based limitations the statute itself would confer citizenship automatically and "at birth." ${ }^{59}$ Congress would have favored such severance, the dissenters reasoned, both because advances in the reliability of proving paternity by DNA testing have overcome concerns that drove the challenged statutory provisions, and because the statute expressly authorizes severance. ${ }^{60}$

While the case was, for all practical purposes, decided on justiciability grounds, the justiciability issues should not mask the real importance of the Miller decision. Although the Court formally sustained Section 309(a), we argue below that the reasoning of a majority of the Justices calls into question the viability, not only of the statute, but of the plenary power doctrine and the Court's past approach to individual rights claims in the area of immigration and naturalization. The justiciability flaws in Ms. Miller's case make the decision appear less significant than it is.

2. Miller as a sex discrimination decision. Section 309(a) draws a sex-based distinction between male and female unwed U.S. parents

\footnotetext{
${ }^{56}$ Id at 1446.

${ }^{57}$ INA $\$ 309(a)(3), 8$ USC $\$ 1409$ (a)(3).

${ }^{58}$ INA $\$ 309(a)(4), 8$ USC $\$ 1409(a)(4)$

$59118 \mathrm{~S} \mathrm{Ct}$ at $1457,1463-64$.

${ }^{60}$ Id at 1463-64.
} 
of foreign-born children. Had Mr. Miller been female, his daughter's U.S. citizenship would have been assured, and the lateness of any efforts to establish a legal and financial relationship would not have mattered. ${ }^{61}$

Only Justice Stevens, joined by Justice Rehnquist, defended the statute as nondiscriminatory. ${ }^{62} \mathrm{He}$ reasoned that the requirement that paternity be established or acknowledged before the child turns eighteen could be justified by three purposes he believed were served by the time limitation on acknowledgment or adjudication of paternity: (1) ensuring reliable proof of a biological relationship between the father and child, (2) encouraging "a healthy relationship between the citizen parent and the child while the child is a minor," and (3) "foster[ing] ties between the foreignborn child and the United States." ${ }^{3}$ He found the statute's sexbased classification to be substantially related to those purposes.

Justice Stevens's central contention was that the statute's different treatment of women and men was justified by "real differences" between the sexes. Differences between the biological functions of men and women in procreation mean that "the unmarried father may not even know that his child exists, and the child may not know the father's identity." In the absence of such knowledge, the father and child may lack even "the opportunity ... to develop a personal relationship." In contrast, a mother will always know that she has borne a child, and "typically will have custody of the child immediately after the birth," giving the child "the opportunity to develop ties with its citizen mother at an early age." Given the fact that male members of the military frequently conceive

\footnotetext{
${ }^{61}$ Although Ms. Miller was not discriminated against based on her own sex, Section 309(a) disadvantaged ber based on her citizen parent's sex-a distinction that also seems fair to describe as sex-based. Compare Palmore v Sidoti, 466 US 429 (1984) (consideration of race of mother's new husband in denying child custody to mother amounts to discrimination based on race). If one accepts this analysis, of course, third-party standing would not be necessary because Ms. Miller would have a first-party claim.

${ }^{62}$ Justice Scalia, joined by Justice Thomas, declined to reach the merits of the sex discrimination issue, $118 \mathrm{~S} \mathrm{Ct}$ at 1446 , and, as discussed below, the other five Justices would have concluded that the statute failed heightened constitutional scrutiny, id at 1445-46 (O'Connor, joined by Kennedy, concurring) (noting that they did "not share Justice Stevens' assessment that the provision withstands heigbtened scrutiny," but believed that it did survive the rational-basis review that they believed to be appropriate); id at 1457-58 (Breyer, joined by Souter and Ginsburg, dissenting) (concluding that the provision could not withstand heightened scrutiny).

${ }^{63}$ Id at $1438-39$.
} 
children abroad and then return home without verifying whether any offspring resulted from their sexual encounters, Justice Stevens believed that Congress had legitimate grounds for concern that out-of-wedlock offspring born abroad of U.S. fathers might lack any ties to the citizen parent and to the United States. In Justice Stevens's view, the additional hurdles imposed on the male citizen parent operate roughly to equalize the likelihood that his child (as compared to the child of a female citizen) will have ties to the citizen parent and hence to the United States. A requirement that a parent seeking to convey citizenship show that there was at least an opportunity for that child to develop such ties "performs a meaningful purpose for citizen fathers, but normally would be superfluous for citizen mothers," and will at least "reduce, rather than aggravate, the disparity between the two classes of children." ${ }^{4}$

Five members of the Court rejected Justice Stevens's conclusion that Section 309(a) could survive heightened scrutiny. Justice O'Connor, joined by Justice Kennedy, did not reach the issue, but nonetheless stated: "I do not share Justice Stevens' assessment that the provision withstands heightened scrutiny," because "[i]t is unlikely ... that any gender classifications based on stereotypes can survive heightened scrutiny." ${ }^{65}$ Justice O'Connor expressed no opinion, however, on whether heightened scrutiny would be the appropriate standard of review for a bloodline citizenship claim. The three dissenting Justices would have applied heightened scrutiny to Ms. Miller's claim whether it was viewed as a first-party or third-party challenge. They argued that sex-based distinctions are subject to a "strong presumption of constitutional invalidity," which was not rebutted by the government's stated purposes for the challenged provisions. ${ }^{66}$ In their view, the statute relied on sex as both an over- and underinclusive proxy for parental ties, and, given workable sex-neutral alternatives, the sex-based classification was not justified by any important governmental interest.

In sum, a majority of the Justices in Miller stated that statutes based on sex-role stereotypes are unconstitutional under heightened scrutiny, and there is reason to believe that they would apply

\footnotetext{
${ }^{64}$ Id at 1439.

${ }^{65}$ Id at $1445-46$.

${ }^{66}$ Id at $1460-63$.
} 
such scrutiny to Lorelyn Miller's citizenship claim. As a sex discrimination case, Miller signals no retreat from the Court's modern sex equality doctrine. Part II explains in more detail, not only why the five Justices who identified a potential equal protection defect in Section 309(a) were correct, but also why we believe that is the only plausible view in light of the Court's precedents.

3. Miller as an immigration and citizenship decision. Just as Miller initially seemed to be a disappointment for women's rights, it also appeared to be a loss for proponents of immigrants' constitutional rights. But in fact, Miller is a victory masquerading as a defeat. Assuming that new plaintiffs can clear the justiciability hurdles, they should win a challenge to Section 309(a). A majority of the Justices concluded that because Ms. Miller was a putative citizenat-birth, Fiallo's special judicial deference to immigration questions did not apply. The Court thus rejected the initial framing of the case as a reprise of Fiallo. As Justice Stevens reasoned, "the question to be decided is whether petitioner is such an alien or whether, as she claims, she is a citizen. Thus, we must address the merits to determine whether the predicate for this argument is accurate." ${ }^{67}$ The three dissenters agreed that Fiallo's deferential standard was inapplicable because Ms. Miller claimed that she was already a citizen. Justice Breyer drew a distinction between jus sanguinis citizenship statutes, and immigration or naturalization statutes: The former, "because they confer the status of citizenship 'at birth,' ... do not involve the transfer of loyalties that underlies the naturalization of aliens, where precedent sets a more lenient standard of review." 68

Justice O'Connor believed that only rational-basis review applied to Ms. Miller's claim, but she relied not on Fiallo, or any characterization of Ms. Miller as an alien, but on her view that petitioner had no third-party standing, and no first-party discrimination claim to which heightened constitutional scrutiny might

${ }^{67}$ Id at $1436 \mathrm{n} 10$. Justice Stevens also thought that deference was unnecessary in any event, because Section 309(a) survived even the heightened constitutional scrutiny ordinarily applicable to sex-based classifications. Id at $1437 \mathrm{n} 11$.

${ }^{68} 118 \mathrm{~S} \mathrm{Ct}$ at 1458. Justice Breyer pointed out that if lenient review applied in Miller, it would also logically apply when a married American couple travel or work abroad and bear a child there-thereby producing a child entitled to citizenship not because of birth on American soil, but because of his parents' citizenship. Justice Breyer thought it would be anomalous for any statute discriminating against such children to be subject to less than full judicial review. Id. 
apply. ${ }^{69}$ Justices Scalia and Thomas alone affirmatively embraced the notion of judicial deference to Congress. ${ }^{70}$ They rejected Justice Breyer's distinction between jus sanguinis citizenship and acquisition of citizenship through naturalization, noting that Congress has equal constitutional authority to set the terms for both. ${ }^{71}$

The Court's decision, therefore, was hardly a defeat in the effort to get heightened judicial scrutiny of Section 309(a). But the even bigger story is that Miller undermines Fiallo itself. The Justices in Miller distinguished their nondeferential treatment of jus sanguinis citizenship from the more deferential stance that the Court has taken on immigration and naturalization claims; Miller thus attempts to leave Fiallo intact. But the Court's efforts to distinguish Miller from Fiallo are unstable. As we will argue below in Part III, jus sanguinis citizenship claims cannot meaningfully be distinguished from immigration and naturalization claims. That suggests that the Court must move in either of two directions: backtrack and disavow even for $j u s$ sanguinis claims the more muscular approach outlined in Miller, or follow the course that we think is both more sound and more likely and abandon its posture of extreme deference for immigration and naturalization claims as well.

\section{Skepticism Well Deserved}

Five Justices in Miller apparently believed that Section 309(a) would not survive heightened scrutiny. Under modern equal protection doctrine, those five Justices plainly had the better view. Section 309(a) impermissibly uses sex as an inexact proxy for other attributes of unwed parents, fosters stereotypes that "reflect and reinforce historical patterns of discrimination,"72 and eschews sexneutral standards that could serve the government's purposes as well or better. The statute is a virtual issue-spotter of equal protection defects.

As the dissenters point out, Justice Stevens's reliance on sexbased generalizations to justify the statute is clear on the face of his own opinion, where he consistently modified his characteriza-

\footnotetext{
${ }^{69}$ Id at 1445 .

${ }^{70}$ See id at 1447 .

${ }^{71}$ Id at 1446 (Scalia opinion); compare id at 1463-64 (Breyer opinion).

${ }^{72} 7 E B$ v Alabama, 114 S Ct 1419, 1428 (1994).
} 
tions of the circumstances of one sex or the other by referring to what "typically," "normally," or "often" happens to women or men. ${ }^{73}$ A core attribute of heightened scrutiny, however, is that it condemns the use of inexact sex-based generalizations. Current "typical" behavior of men as a group and women as a group may itself result from historical sex-based bias, and thus must not be relied on to justify further inscribing those differences into the law. ${ }^{74}$ Sex-based generalizations are also prohibited because they deny opportunities to individuals who do not conform to socially defined roles. ${ }^{75}$ Thus, even where sex-based generalizations have some factual accuracy, the Court has consistently invalidated legal restrictions based on them. ${ }^{76}$ As Justice O'Connor wrote in $7 E B v$ Alabama, the constitutional determination that sex must not be used as a proxy for attitude or behavior is "a statement about what this nation stands for" even where it may not be "a statement of fact." 77 It is not enough, under equal protection heightened scrutiny, to conclude as Justice Stevens did that an unmarried mother typically will have emotional or cultural ties with her biological child, while an unmarried father often will not. It is no doubt cur-

${ }^{73} 118 \mathrm{~S} \mathrm{Ct}$ at 1438 ("The blood relationship to the birth mother ... is typically established by hospital records and birth certificates"); id at 1439 (mother "typically will have custody of the child immediately after birth"; requirement that father take affirmative acts to demonstrate the possibility that their child will develop ties to the U.S. "normally would be superfluous for citizen mothers"; mother "often has custody at birth").

${ }^{74}$ See $7 E B v$ Alabama, $114 \mathrm{~S} \mathrm{Ct}$ at 1428 (law must not "reflect and reinforce patterns of historical discrimination"); Craig v Boren, 429 US 190, 202 n 14 (1976) (rejecting proffered justification for different beer-purchase ages for males and females based on higher risk of males having alcohol-related safety problems, the Court reasoned that "[t]he very social stereotypes that find reflection in age differential laws are likely substantially to distort the accuracy of . . comparative statistics" regarding drinking and driving).

${ }^{75}$ United States v Virginia, 518 US 515 (1996); Mississippi Univ. for Women v Hogan, 458 US 718,725 (1982).

${ }^{76}$ Although sex-based generalizations may contain "a measure of truth" or empirical accuracy, heightened scrutiny prohibits using sex as a proxy, unless it is supported by an "exceedingly persuasive" governmental justification for doing so. Virginia, 116 US at 2274; Hogan, 458 US at 724; see Craig, 429 US at 200-201 (invalidating differential beer purchase ages for men and women despite statistics showing that young men presented greater safety risks from drunk driving than did young women); Weinberger $v$ Weisenfeld, 420 US 636, 645 (1975) (invalidating sex-based social security survivors' benefits despite "empirical support" for the conclusion that men are more likely than women to be primary breadwinners); Frontiero $v$ Richardson, 411 US 677, 688-89 (1973) (plurality opinion) (invalidating presumption of wives' but not husbands' dependency for purposes of benefits determinations despite the "empirical" fact that "wives in our society frequently are dependent on their husbands, while husbands rarely are dependent on their wives").

${ }^{77} 114 \mathrm{~S} \mathrm{Ct}$ at 1432 (O'Connor concurring). 
rently true that greater numbers of out-of-wedlock children have more significant ties to their mothers than to their fathers, and that many do not know their fathers at all. But as Judge Wald noted in her concurrence in the court of appeals' decision, "there is a world of difference between noting that men and women often fill different roles in society and using these different roles as the justification for imposing inflexible legal restrictions on one sex and not on the other." 78

Concrete examples make clear that Section 309(a) is both underand overinclusive, and show why that poor fit makes the law incompatible with the Supreme Court's sex discrimination decisions. Section 309(a) fails to require proof of a legal relationship or financial support obligations on the part of mothers even when they do not fulfill the statute's underlying assumption of maternal ties. Anyone who has watched the popular film "Secrets and Lies" or read Charles Dickens's Bleak House knows that biological mothers do not always develop ties with their biological children or, regrettably, even know that their child has survived. An unmarried U.S. woman might abandon a child she had with a foreign man to whom she was not married because she was ashamed to return to the United States with the child. ${ }^{79}$ An unmarried mother might have no interest in child rearing, or might be drug addicted or mentally ill and unable to care for an infant, and thus might abandon it. Section 309(a) is also plainly overinclusive. A nonmarital child raised from infancy by an American father, whether on his own or with help from the foreign mother or other family members, would have precisely the ties to the citizen parent and the United States that Section 309(a) seeks to foster, and yet the father would have to fulfill additional requirements not demanded of a women in his situation in order to convey his citizenship. Finally, even where its requirements are met, Section 309(a)(3) does not assure any tie to a U.S. citizen father, because it permits a biological child to obtain an adjudication of paternity without any affirmative act by the father, and perhaps even over his express objection. A child thus could, at least in theory, obtain U.S. citizenship

\footnotetext{
${ }^{78} 96 \mathrm{~F} 3 \mathrm{~d}$ at 1475 (Wald concurring).

${ }^{79}$ For example, a female member of the armed services with a sweetheart back home might leave the child she conceived with a foreign lover with him or his family in order to return to the United States to pursue her life as she had previously envisioned it.
} 
despite a wholly antagonistic relationship with, or complete alienation from, a U.S. parent. ${ }^{80}$ The dissenters correctly characterized the relationship between the statutory requirements and the government's asserted objectives as one of "total misfit." ${ }^{11}$

By assuming away the admittedly atypical cases-the closely involved father and the careless mother-Section 309(a) gives legal weight to restrictive stereotypes about men's and women's parenting roles. Women are assumed to be caretakers of children; men are assumed not to be. Fathers are thought to be breadwinners who should financially support their children, whereas financial support from mothers is beside the point, whether because mothers are believed not to earn significant income or because it is taken for granted that they will behave generously toward their own offspring and voluntarily support them financially.

Those sex-role stereotypes contribute to sex inequality. ${ }^{82} \mathrm{Be}-$ cause women, not men, are expected to be caretakers of their children, there is generally greater (although still marginal) social and institutional acceptance of women than of men who take parenting leaves, cease outside employment, remain longer in less demanding jobs, or work part time in order to spend time rearing young children. ${ }^{83}$ Women as a group disproportionately bear the corresponding costs of being primary caretakers in the form of less compensation, professional advancement, and self-fulfillment through work. And when men are not seriously expected to be primary or significant caretakers of their children, they as a group bear costs in terms of less intimacy with their children and self-fulfillment through parenting. These sex-role stereotypes restrict the individual choices of both sexes. ${ }^{84}$ Sex-role stereotypes about parenting,

\footnotetext{
${ }^{80}$ But see text at notes $88-92$.

${ }^{81}$ Miller, $118 \mathrm{~S} \mathrm{Ct}$ at 1461.

${ }^{82}$ The Court has been particularly unwilling to sustain sex-based classifications that reinforce gender stereotypes. See Hogan, 458 US at 725 ("[c]are must be taken in ascertaining whether the [government's] objective itself reflects archaic and stereotyped notions."); Orr $v$ Orr, 440 US 268, 283 (1979) (alimony for women but not men invalidated in part because it carried "the baggage of sexual stereotypes"); Stanton v Stanton, 421 US 7, 15 (1975) (different ages of majority for girls and boys relied on the "role-typing that society has long imposed").

${ }^{83}$ This is not to suggest that fathers do not get disproportionate credit for fulfilling even a small portion of child rearing and household responsibilities, but rather that fathers who take an equal or predominant role in child rearing and make career sacrifices for it are viewed as strange.

${ }^{84}$ The assumption reflected in the text that men's roles in caring for their children affect women includes an assumption that the mother at least potentially shares child rearing with
} 
and the legal and social institutions that reinforce them, are a major remaining obstacle to social and economic equality and choice for both women and men. ${ }^{85}$

Section 309(a) not only builds on traditional parenting roles, but also provides concrete benefits to men that it denies to women, and does so in a way that reflects and reinforces men's, but not women's, sexual irresponsibility. The statute effectively gives U.S. men, but not U.S. women, a choice to disavow the children they conceive with foreign partners. Justice Stevens may be right to characterize as relatively low the hurdles that Section 309(a) places before fathers who are aware of the statute's deadlines and motivated to have their children become U.S. citizens. ${ }^{86}$ But his view fails to capture the way the provision may also benefit men by letting fathers, but not mothers, off the hook. Not every unwed U.S.-citizen father will view conveying citizenship to his child as a benefit to himself. ${ }^{87}$ A serviceman who has had unprotected sex overseas with a woman to whom he is not married, and who does not want any child conceived in that encounter following him to the United States, claiming him as her father and demanding financial support, may well be relieved that Section 309(a) renders his child's U.S. citizenship less than automatic. As we have

a man. Mothers in lesbian couples, and single mothers who prefer no involvement from the biological father, would obviously not be directly affected by greater male involvement in parenting. See Christine A. Littleton, Does It Still Make Sense to Talk About "Women"? 1 UCLA Women's Law J 15, 29-30 (1991). To the extent that more male caretaking might increase the impetus hehind social changes such as affordable, high-quality childcare and the normalization of shorter or more flexible working hours, however, such a change would ameliorate some of the economic inequality that female households currently experience. But cf. Littleton, id (characterizing those issues as workers' rights, rather than women's rights, concerns). And hreaking down dichotomous, sex-based social expectations is part of freeing all women (and men) to make the choices that inatch their vision of a good life.

${ }^{85}$ As Professor Martha Fineman has pointed out, "[a]ll women must care about social and legal constructions of motherhood, because, although we may make individual choices not to hecome a mother, social construction and its legal ramifications operate independent of individual choice," affecting all women, whether they are mothers or not. Martha L. A. Fineman, Feminist Theory and the Law, 18 Harv J L \& Pub Pol 349, 364 (1995).

${ }^{86} \mathrm{See} 118 \mathrm{~S} \mathrm{Ct}$ at 1440 . There are, however, many plausible reasons that a motivated father might fail to meet the statute's age-eighteen deadline: He might be unaware of the law. He might not recognize the benefits of U.S. citizenship for the child until the child was over eighteen because, for example, elderly grandparents in the United States only then began to need care and the company of their descendants, or because the reality of limited einployment opportunities for noncitizens in the United States only began to seem relevant when the child reached an age when she needed employment.

${ }^{87}$ Some U.S. mothers similarly might not want to convey their citizenship to their nonmarital children born abroad, but the statute does not give operative significance to their ambivalence the way it does for men. 
seen, Section 309(a) discriminates against the caring father who wants to convey his citizenship but did not know about the law or recognize until too late the importance of U.S. citizenship for his children; but it also discriminates in favor of the careless father by making it easier for him to ignore his overseas, out-of-wedlock offspring. In the words of Professor Karen Czapanskiy, it reinforces social treatment of mothers as "draftees" into a parental role and fathers as "volunteers." 88 Those effects, apparently unnoticed by the Justices, are not tolerable under any theory of sex equality.

As a formal matter, Section 309(a)(4)(C) does permit a child to seek a paternity adjudication against an unwilling father, so a father cannot be certain that his decision not to legitimate or acknowledge his child will prevail. As a practical matter, however, his decision will virtually always be definitive. In order to override his preference, a child overseas (or her foreign mother in her behalf) would have to know about the statute, and specifically about her opportunity under Section 309(a)(4)(C), to get a court adjudication, locate the correct state court in the United States, hire a lawyer, and file and win an involuntary paternity action. If she managed to get that far, she would still have to satisfy Section 309(a)(3)'s financial-support prong. It is not at all clear that a childsupport order would count as "agree[ing] in writing to provide financial support" under the statute, but even if it did, the child would face similar logistical obstacles to obtaining such an order. And the nonmarital child abroad might have no substantive right to support from a U.S. father if, for example, the law of the place of birth applied and conferred no such right, and if the relevant U.S. domestic law did not apply extraterritorially.

Of course, if statistics regarding paternal nonsupport of nonmarital children are any guide, ${ }^{89}$ the very fact that Section 309(a) requires the father to acknowledge his support obligations will likely deter many fathers from taking advantage of Section 309(a) voluntarily to confer citizenship on their children. Justice Stevens im-

\footnotetext{
${ }^{88}$ See Karen Czapanskiy, Volunteers and Draftees: The Struggle for Parental Equality, 38 UCLA L Rev 1415 (1991).

${ }^{89}$ One estimate states that only 37 percent of noncustodial fathers of nonmarital children pay any of their court-ordered child support, Melissa Fletcher Stoeltje, Counting on Cbild Support, Houston Chronicle (Jan 26, 1997), and the figure is presumably substantially lower for the vast category of such children for whom no court order has been obtained.
} 
plicitly recognized as much when he asserted that the age-eighteen deadline helps to prevent U.S. males from fraudulently claiming paternity because it requires that the claim be made during the child's legal minority, when the man would risk liability for child support. ${ }^{90}$ But Justice Stevens neglected to draw the related conclusion that it is at least equally plausible that a child's biological father would likewise be deterred from making a bona fide paternity claim. ${ }^{91}$ As much as we may condemn such irresponsible parental behavior, the truth is that Section 309(a)(3) gives irresponsible U.S. fathers valuable financial freedoms that it denies to U.S. mothers. $^{92}$

Justice Stevens understood his analysis to depend not on stereotypes or generalizations, but on a "real" difference between women, who at least are aware whether they have biological offspring, and men, who may not be. That difference does, to be sure, stem from the fact that biological mothers, by physically bearing children, must be aware of them at birth in a way that fathers need not be. The problem with Justice Stevens's analysis, however, is that the knowledge that comes from giving birth bears only a loose-and constitutionally inadequate-relationship to the interest in family bonds and ties to the United States. The relationship between the mother's unique biological role and the interest in fostering children's ties to their citizen parents depends on the stereotyped generalization that an unmarried mother, as a result of having given birth, can be legally presumed to develop a caring relationship with the child after the child's birth during its legal

\footnotetext{
${ }^{90} 118 \mathrm{~S} \mathrm{Ct}$ at $1439 \mathrm{n} 15$.

${ }^{91}$ Given the ambiguous value to fathers as a class of any decision invalidating Section 309(a), Justice O'Connor's conclusion that Ms. Miller lacked third-party standing is particularly troubling. Although he did not so argue, Mr. Miller or other men in his situation may well be "hindered" from raising constitutional objection to Section 309(a) by the prospect of having their children come to the United States and seek their financial support. And a U.S. citizen mother who seeks the "benefit" of an equal opportunity to ignore her outof-wedlock offspring born abroad is in no position to sue to challenge Section 309(a).

${ }^{92}$ Allowing U.S. fathers to elect not to convey citizenship on their foreign-born children is also a policy with ugly class and race implications when U.S. fathers conceive children abroad with poor and/or minority women. As noted above, alien children abroad will often be unable to claim financial support from their U.S. fathers. Thus, the option that Section 309(a) protects for U.S. fathers not to convey citizenship to such children gives those fathers more latitude not to take financial responsibility for their nonmarital child born abroad of foreign mothers than they have under domestic law vis-à-vis nonmarital children born in the United States.
} 
minority, while the biological father cannot. ${ }^{93}$ As Justice Breyer noted, to the extent that Section 309(a)(4) is merely a means to assure that fathers know of their children's existence just as mothers inevitably do as a result of having given birth,

[t] he distance between this knowledge and the claimed objectives ... is far too great to satisfy any legal requirement of tailoring or proportionality. ... Simple knowledge of a child's existence may, or may not, be followed by the kinds of relationships for which Justice Stevens hopes. A mother or a father, knowing of a child's birth, may nonetheless fail to care for the child or even to acknowledge the child. A father with strong ties to the child may, simply by lack of knowledge, fail to comply with the statute's formal requirements. A father with weak ties might readily comply. ${ }^{94}$

To be sure, knowledge of a child's existence is a prerequisite to developing a relationship with that child, but a sex-neutral alternative to Section 309(a) readily could require that citizenship be conveyed only from biological parents who know their children and demonstrate the kind of familial ties that the government values. Justice Stevens also fell far from the mark in seeking to justify the statute as a way roughly to equalize the burdens that biological mothers and fathers bear in having children, or to reward mothers for the physical risks, discomfort, and pain of pregnancy and childbirth. ${ }^{95}$ The government's stated objective behind Section 309(a) is to ensure that jus sanguinis citizens have ties to the United States through their citizen parent; it has never been to reward women for childbirth, or to offset the physical burdens they suffer. Indeed, if that were the objective, it would be strange to pursue it only in the context of unmarried, and not married, mixed-citizenship couples. In any event, because the physical sacrifices biological mothers make before and during birth do not ensure the development of the parental ties the statute seeks to foster, those sacrifices do

\footnotetext{
${ }^{93}$ Id at 1461.

${ }^{94} \mathrm{Id}$ at 1462 .

${ }^{95}$ Id at 1437 (Stevens opinion) ("If the citizen is the unmarried female, she must first choose to carry the pregnancy to term and reject the alternative of abortion.... She must then actually give birth to the child. Section 309(c) rewards that choice and labor by conferring citizenship on her child." In contrast, "all that $\$[309$ (a)(4)] requires is that [the biological father] be willing and able to acknowledge his paternity in writing under oath while the child is still a minor. . . It seems obvious that the burdens imposed on the female citizen are more severe than those imposed on the male citizen").
} 
not substantially relate, any more than mere knowledge of birth, to the statutory objective of fostering ties to the United States.

The stereotypical use of sex as an inexact proxy for parental ties is especially problematic in view of the ready availability of sexneutral alternative measures to serve the government's stated objectives. ${ }^{96}$ The objectives of reliably determining biological parenthood and promoting ties to the United States could be equally well served by sex-neutral requirements applicable to all nonmarital children born abroad of mixed-citizenship unions. The Miller dissenters aptly pointed out that Congress "could simply substitute a requirement of knowledge-of-birth for the present subsection (a)(4); or it could distinguish between caretaker and non-caretaker parents, rather than between men and women." 97 Alternatively, ties to the United States could be established by requiring out-ofwedlock children to seek citizenship before they turn eighteen, ${ }^{98}$ or by requiring that the caretaker parent have lived in the United States. ${ }^{99}$

The need for reliable proof of biological parenthood can also be met as well or better by sex-neutral measures than by the statute's current requirements. The statute could simply require that both mothers and fathers prove their parenthood by clear and convincing evidence. The additional requirement that only fathers meet a deadline for establishing a formal legal relationship with their children is not needed to ensure accuracy of paternity determinations. The assumptions behind the statutory requirement that fathers but not mothers prove their biological relation to the child are that maternity is universally and reliably established by birth

${ }^{96}$ Where governmental purposes are "as well served by a gender-neutral classification as one that gender classifies and therefore carries with it the baggage of sexual stereotypes, the [government] cannot be permitted to classify on the basis of sex." Orr v Orr, 440 US 268, 283 (1979).

${ }^{97} 118 \mathrm{~S} \mathrm{Ct}$ at 1463 (Breyer dissenting).

${ }^{98}$ See 8 USC $\$ 1431(a)(1), 1432(a)(4)$ (providing in sex-neutral terms that a foreignborn child who does not become a citizen at birth may in certain circumstances obtain derivative citizenship if one or both parents is a citizen, but only if the child seeks naturalization before age eigbteen).

${ }^{99}$ Children born abroad before 1934 of one U.S. citizen parent are U.S. citizens, provided only that their citizen parent-whether male or female-have resided in the United States. See Section 1993 of the Revised Statutes of 1874 (quoted in Wauchope $v$ United States Department of State, 985 F2d 1407, 1410 n 1 (9th Cir 1992)) (providing citizenship for children of U.S. fathers); INA $\$ 301(\mathrm{~h}), 8$ USC 1401(h) (equalizing Section 1993 by providing for citizenship of children of U.S. mothers). 
itself, whereas paternity is difficult to prove and subject to fraud, especially with the passage of time. Both assumptions are questionable. Recent studies show that one-third of all births abroad occur without birth certificates. ${ }^{100}$ That reality, especially when coupled with the increased incidence of adoptions from abroad, suggests a need for proof of maternity by U.S.-citizen putative mothers before the children they assert they bore overseas are recognized as jus sanguinis U.S. citizens. As for fathers, the notion that requiring them to undertake a formal act establishing paternity before their child turns eighteen "lessens the risk of fraudulent claims made years after" 101 is no longer true in light of the availability of highly accurate DNA testing, the reliability of which does not wane over time..$^{102}$

Justice Stevens found apparent support for his defense of Section 309(a), however, in Lebr $v$ Robertson, ${ }^{103}$ an equal protection decision that upheld under heightened scrutiny a sex-based classification grounded in part on the generalization that the birth mother has stronger parental ties than the father. The statute in Lebr automatically gave mothers of illegitimate children prior notice of a proposed adoption, but extended the same right to unmarried fathers only if they had taken an affirmative step to claim paternity, such as by entering their names in the state's "putative father registry." 104 A biological father challenged the adoption by the biological mother's husband of a child the father had never supported and rarely seen, arguing that his failure to receive prior notice and a right to veto the adoption violated due process and equal protec-

\footnotetext{
${ }^{100}$ Associated Press, U.N.: Lack of Birtb Papers Harming Millions of Kids, Chicago Tribune (July 9, 1998) (discussing figures in UNICEF report entitled The Progress of Nations 1998).

${ }^{101} 118 \mathrm{~S} \mathrm{Ct}$ at 1440 (Stevens opinion).

${ }^{102}$ Justice Stevens protested that DNA testing may be expensive and more intrusive than the methods of establishing paternity required in Section 309(a). $118 \mathrm{~S} \mathrm{Ct}$ at 1439 \& $\mathrm{nn}$ 12-13. DNA testing need not, of course, be the only permissible method of proof, but the fact that it exists and may be used in cases in whicb other evidence is unavailable or stale alleviates the concern regarding reliable proof that the government asserts in support of Section 309(a). And the costs of DNA testing presumably pale in comparison to the financial support obligations a father must shoulder under Section 309(a)(3).

${ }^{103} 463$ US 248 (1983); see also Quilloin v Walcott, 434 US 246, 252 (1978) (unanimously sustaining against due process cballenge a state law that denied biological fathers but not mothers of nonmarital children authority to veto adoption, and affirming adoption by mother's husband who had played paternal role for child for several years before adoption).
}

${ }^{104} 463$ US at 251-52. 
tion. In rejecting the equal protection claim, the Court, per Justice Stevens, underscored that the father did not "complain of his exemption from the] responsibilities" of supervising, educating, protecting, and caring for the child. ${ }^{105}$ The Court distinguished Caban $v$ Mohammed, in which the Court four years earlier had found an equal protection defect in a similar sex-based adoption provision, on the ground that the mother and father in Caban were in fact similarly situated, whereas the Lebr parents were not. ${ }^{106}$ The Lebr Court concluded that, "[i]f one parent has an established custodial relationship with the child and the other parent has either abandoned or never established a relationship, the Equal Protection Clause does not prevent a State from according the two parents different legal rights." 107

Given the availability of sex-neutral mechanisms for assessing whether a custodial or other active parenting relationship has been established, Lebr's tolerance of a state statute that used sex as an inexact proxy for parental ties is hard to square with the rest of the Court's sex discrimination cases. ${ }^{108}$ The case might itself be seen as a reaffirmation of the Court's commitment to sex neutrality; after all, the concluding passage in Lebr states the issue in gender-neutral terms, underscoring the fairness of treating differently, not men and women, but custodial and noncustodial parents. ${ }^{109}$ But a puzzle remains, because the statute in Lehr used sex, not those gender-neutral categories, as the basis for distinguishing among parents entitled to notice and those who were not. Under the Supreme Court's other sex equality cases, the Lebr result (notice to the custodial parent but not the absentee parent) may well be constitutionally permissible, but the means-the use of a sex-based classification-is not. Lehr might be viewed as an as-applied chal-

\footnotetext{
${ }^{105} \mathrm{Id}$ at 267.

${ }^{106}$ Id at 267-68, citing Caban, 441 US 380 (1979).

${ }^{107} 463$ US at $267-68$.

${ }^{108}$ This is especially so if one credits suggestions that the Court's Virginia decision ratcheted up the standard of review of sex-based classifications. See Virginia, $116 \mathrm{~S} \mathrm{Ct}$ at 2294 (Scalia dissenting) (asserting, without contradiction by the majority, that the Court's decision effectively accepted the government's argument that strict scrutiny should apply to sex-based classifications); see generally Babcock, Freedman et al., August 1996 Professors' Update to Sex Discrimination and the Law: History, Practice, and Theory Second Edition, Materials on the Virginia Military Institute (VMI) Case, 36-38, 44.
}

${ }^{109} 118 \mathrm{~S} \mathrm{Ct}$ at 267-68. 
lenge, upholding the statute only insofar as the statute's sex-based generalization is accurate. That reading, too, seems inadequate, however, because the equal protection defect inheres in any use of the sex-based classification itself, not only in those applications where it is inaccurate. ${ }^{110}$

In any event, Miller is different from Lebr, as suggested by the fact that Justice O'Connor joined the majority in Lebr but concluded in Miller that Section 309(a) would not withstand heightened scrutiny. Lebr reflects a special concern that difficulties in verifying the paternity of a putative father could delay an adoption that was in the child's best interests. ${ }^{111}$ Such a concern is not applicable in Miller, and, as Justice Breyer suggested, it may no longer apply even in the adoption context because the availability of DNA testing can quickly erase doubts about paternity and expedite the process. ${ }^{12}$ Lebr may more generally be viewed as an expression of the Court's solicitousness toward placement of children with intact nuclear families, ${ }^{113}$ a value that does not appear to be directly relevant to the INA's different treatment of unwed mothers and fathers. Finally, Lebr may also reflect a related perception that granting a biological, noncaretaker father a right to veto his child's adoption by the mother's new husband would have detracted from

\footnotetext{
${ }^{110}$ See Northeastern Florida Chapter of Associated General Contractors $v$ facksonville, 508 US 656 (1993) (recognizing standing to challenge a racial classification even where a raceneutral alternative admittedly would have had the same effect on the plaintiff as the challenged classification, because " $[t]$ he 'injury in fact' in an equal protection case of this variety is the denial of equal treatment resulting from the imposition of the barrier, not the ultimate inability to obtain the benefit"); Heckler v Matbews, 465 US 728, 739 (1984) (recognizing standing even where remedy could equalize men's and women's benefits by nullifying those afforded to the favored sex, rather than extending them to the disfavored sex, because "discrimination itself, by perpetuating 'archaic and stereotyped notions' or by stigmatizing members of the disfavored group as 'innately inferior' and therefore less worthy participants in the political community, can cause serious noneconomic injuries to those persons who are personally denied equal treatment solely because of their membership in disfavored group"). These cases suggest that the father in Lebr suffered an equal protection injury from the mere application of the statute, even if the result was constitutionally permissible in that case.

"11 See 468 US at 257.

${ }^{112}$ See $118 \mathrm{~S}$ Ct at 1463 (Breyer dissenting).

${ }^{113}$ Professor Marjorie Schultz analyzes Lebr in the context of competing models of biological versus social fatherhood, and characterizes the decision as expressing the Court's "preference for conventional nuclear families over biological connection in certain circumstances." Marjorie Schultz, Reproductive Technology and Intent-Based Parentbood: An Opportunity for Gender Neutrality, 1990 Wis L Rev 297, 317-18.
} 
the caretaking mother's ability to carry out her own plans for herself and her child. ${ }^{114} \mathrm{~A}$ sex-neutral INA would not have the same zero-sum effects as between fathers' and mothers' choices. If, for example, Ms. Miller obtained U.S. citizenship, she would not be required to leave her mother and move immediately to the United States to join her father; moreover, Ms. Miller's citizenship could be of substantial benefit to her mother, because it would give Ms. Miller the opportunity eventually to bring her mother to the United States as well. ${ }^{115}$ In sum, even assuming that Lebr remains valid, Section 309(a) cannot be squared with the Court's established equal protection doctrine prohibiting sex-based classifications that are not supported by "exceedingly persuasive" justifications. ${ }^{116}$

* * *

Viewed without deference, Section 309(a) imposes unconstitutional sex discrimination. Justice Stevens's reasoning to the contrary not only apparently failed to persuade a majority of the Court, but is wrong under established constitutional analysis. As noted above, what allowed Section 309(a) to stand, at least for now, was not that the law was free from equal protection defect, but that Justices O'Connor and Kennedy thought the wrong plaintiff was before the Court.

That brings into focus three issues of continuing importance. The first question-our answer to which follows from the preced-

\footnotetext{
${ }^{114}$ See also Planned Parentbood of Central Mo. v Danforth, 428 US 52, 71 (1976) (sustaining statute that gives women's interest in deciding whether to terminate a pregnancy priority over men's in light of "the obvious fact that when the wife and the husband disagree on this decision, the view of only one of the two marriage partners can prevail"). Recognition of a right on the part of biological mothers whether to cboose abortion without a corresponding (and potentially conflicting) right of biological fathers derives from the fact that women and men are not similarly situated with respect to the physical and emotional consequences of bearing children. See Planned Parentbood of Soutbeastern Pennsylvania v Casey, 505 US 833, 896 (1992) (invalidating spousal notification requirement, and recognizing that "[i]t is an inescapable biological fact that state regulation with respect to the child a woman is carrying will have a far greater impact on the mother's liberty than on the father's"); Danforth, 428 US at 69,71 (invalidating spousal consent requirement, and commenting that "[i]nasmuch as it is the woman who physically bears the child and who is the more directly and immediately affected by the pregnancy, as between the two, the balance weighs in her favor"). Viewing Section 309(a) as constitutionally problematic does not call into question the validity of women's exclusive right to reproductive choice.

${ }^{115} 1 \mathrm{~mm}$ ediate relatives (including parents) of citizens of the United States may be admitted to the United States without being counted against numerical immigration limitations. INA $\$$ 201(b), 8 USC $\$ 1151(\mathrm{~b})$.

${ }^{116} \mathrm{Hogan}, 458$ US at 724-25.
} 
ing analysis-is how courts faced with plaintiffs who do have standing should evaluate constitutional challenges to Section 309(a). A lower federal court that reads Miller and counts votes should understand that the Supreme Court in all probability would, if it reached the merits, review the statute nondeferentially and-if a majority agrees with Justice Breyer rather than Justice Scalia on the remediability point-hold it unconstitutional. ${ }^{117}$ Thus, the government's victory in Miller is likely to be short-lived, and, indeed, ought not survive the next case.

The second question is whether courts reviewing sex discrimination claims in the area of immigration and nationality generally should continue to apply deferential review to express sex-based classifications. We address this issue in Part III, where we argue that Miller's recognition that the political branches do not require deferential judicial review in the bloodline citizenship context puts great pressure on prevailing doctrine that deference is warranted in the immigration and nationality area generally. As Judge Wald aptly suggested in her concurring opinion in the court of appeals, ${ }^{118}$ it is time for the Court to reconsider the plenary power doctrine.

Section 309(a)'s constitutional infirmity under heightened scrutiny also raises a third issue: what the political branches should have done when first faced with the proposed 1986 amendments to Section 309(a), and where the political branches should go from here in dealing with sex-based classifications in immigration law. We argue in Part IV that the political branches have responsibilities to comply with the Constitution that are independent of the Court's willingness (or not) to enforce constitutional norms. Those responsibilities mean that the political branches generally should apply full constitutional scrutiny to immigration and nationality measures and, in particular, that when they amended the INA in 1986 they should have rendered an independent constitutional judgment as to whether Section 309(a)'s sex-based distinctions should have been replaced with sex-neutral alternatives. The executive branch's constitutional responsibilities also suggest that, in light of Miller and the arguments we present in Part II, the State

117 See note 52 .

${ }^{118}$ Miller v Christopher, 96 F3d at 1477 (Wald concurring). 
Department should stay its enforcement of Section 309(a) and work with Congress to enact a sex-neutral substitute.

\section{Plenary Power and Political Questions}

\section{A. PLENARY POWER AS JUDICIAL UNDERENFORCEMENT}

For more than a century, immigration law has been haunted by the so-called plenary power doctrine, a Court-crafted rule of extreme judicial deference to congressional and executive exercises of the immigration power. ${ }^{19}$ The doctrine has never been applied to all cases involving aliens. The Court has made clear that outside the immigration and naturalization context, immigrants (even unauthorized migrants ${ }^{120}$ ) enjoy most of the constitutional rights afforded citizens; ${ }^{121}$ and state regulations that discriminate on the basis of alienage (other than those involving political rights) will be strictly scrutinized. ${ }^{122}$ Even within the field of immigration regulation, the Court made an exception to the plenary power doctrine when it nondeferentially applied due process norms to removal proceedings. ${ }^{123}$ In the main, however, courts exhibit extraordinary restraint in reviewing substantive immigration and naturalization regulations-specifically, classifications of which aliens shall be entitled to enter and remain in the United States and the terms of their residence-whether or not the regulations establish categories or implicate rights in a manner that normally invokes more active judicial scrutiny.

The cases offer a common theme as the justification for judicial deference. The government's brief in Miller, noting that "[d]eferential review of legislation concerning immigration and nationality

\footnotetext{
${ }^{119}$ See Gerald L. Neuman, Strangers to the Constitution: Immigrants, Borders, and Fundamental Law, ch 7 (Princeton, 1996); Stephen H. Legomsky, Immigration and the 7udiciaryLaw and Politics in Britain and America, ch 3 (Oxford, 1987); Stephen H. Legomsky, Immigration Law and the Principle of Plenary Congressional Power, 1984 Supreme Court Review 255; Hiroshi Motomura, Immigration Law After a Century of Plenary Power: Phantom Constitutional Norms and Statutory Interpretation, 100 Yale L J 545, 545, 573-74 (1990).

${ }^{120}$ Plyler $v$ Doe, 457 US 202 (1982) (invalidating Texas statute denying public education to undocumented immigrant children).

${ }^{121}$ United States $v$ Balsys, 118 S Ct 2218, 2222 (1998); Wong Wing v United States, 163 US 228, (1896).

${ }^{122}$ Grabam v Richardson, 403 US 365, 375 (1971).

${ }^{123}$ Landon v Plasencia, 459 US 21, 32 n 7 (1982); Yamataya v Fisher, 189 US 86 (1903).
} 
is not a relic of the past," summarized the argument as follows: the power to regulate immigration is "a necessary and inherent attribute of national sovereignty," its exercise implicates U.S. relations with foreign powers, and policies regarding admission to the U.S. and acquisition of citizenship are "uniquely political in character." 124 This, however, is more a laundry list than an exercise in logic. When one separates out the items, one sees that cases decided in the nineteenth century exhibit a judicial strategy distinct from that displayed in the modern cases.

The nineteenth-century cases announced constitutional holdings about the scope of congressional power. Consistent with the categorical judicial style of the day, ${ }^{125}$ the Court purported to distinguish separate spheres for the judiciary and the political branches. The judiciary would police those boundaries, but it would not intrude into issues squarely within the province of the nonjudicial branches. Such issues were labeled "political"-meaning, appropriate for resolution by the political branches. In calling a question "political" the Court had already concluded that Congress or the executive was operating within constitutional or statutory limits, and that therefore no further substantive judicial review of the challenged conduct was warranted. ${ }^{26}$

Thus, in Fong Yue Ting $v$ United States, the Court noted that, in exercising the power of judicial review, "it behooves the court to be careful that it not undertake to pass upon political questions, the final decision of which has been committed by the Constitution to the other departments of government."127 In more modern terms, we would say that the nineteenth-century Court would not second-guess the legislature or executive branch on issues of policy. That this is the Court's meaning is made clear later in the same opinion:

${ }^{124} \mathrm{Br}$ for Resp at 22. See Harisiades $v$ Shaughnessy, 342 US 580, 588-89 (1952); Fong Yue Ting $v$ United States, 149 US 698, 713 (1893); Chinese Exchusion Case (Chae Chan Ping v United States), 130 US 581, 604 (1889) ("If [a nation] could not exclude aliens it would be to that extent subject to the control of another power.").

${ }^{125}$ See Duncan Kennedy, Toward an Historical Understanding of Legal Consciousness: The Case of Classical Legal Thought in America, 1850-1940, 3 Res in L \& Soc'y 3, 8 (1980).

${ }^{126}$ For example, in Marbury v Madison, Chief Justice Marshall separated cases appropriate for judicial resolution from "questions in their nature political"- that is, cases where executive officers "perform duties in which they have a discretion." 5 US (1 Cranch) 137, 170 (1803).

${ }^{127} 149$ US 698, 712 (1893) (emphasis supplied). 
The question whether, and upon what conditions, these aliens shall be permitted to remain within the United States being one to be determined by the political departments of the government, the judicial department cannot properly express an opinion upon the wisdom, the policy or the justice of the measures enacted by Congress in the exercise of the powers confided to it by the Constitution over the subject. ${ }^{128}$

In these cases, the Court concluded, as a matter of substantive constitutional law, that the Constitution has not been violatedeither because the Constitution does not speak to the question (we will call this the "no law" position), or because the exercise of authority is clearly within the legitimate domain of the legislature or executive. ${ }^{129}$

The modern cases are structured quite differently, though they cite and quote the late nineteenth-century cases. The Court's categorical reasoning has been replaced by twentieth-century discussions of the appropriate level of scrutiny to be applied to the immigration or nationality regulation at issue. The Court thus talks not about matters being confided to the final judgment of the political branches, but rather of "the need for special judicial deference" 130 and the appropriateness of "narrow review of decisions made by the Congress or the President in the area of immigration and naturalization." 131

What accounts for the extraordinary deference of the courts in the modern cases? There are two possibilities. The Court may be applying a different set of substantive constitutional rules to immigration and naturalization laws than it would apply to similar distinctions in the domestic context. (We will call this the "substantive norm" position.) Alternatively, the Court may believe that the same substantive norms govern immigration as other matters but that the norm should be partially suspended for institutional reasons going to the appropriateness of the exercise of judicial power (the "institutional deference" position). Institutional deference, in turn, might have two sources. A court may conclude that such deference is constitutionally based, or it may exercise judicial restraint

\footnotetext{
${ }^{128}$ Id at 731.

${ }^{129}$ See Louis Henkin, Is There a Political Question Doctrine? 85 Yale L J 597, 601, 61012 (1976).

${ }^{130}$ Fiallo v Bell, 430 US 787, 793 (1977).

${ }^{131}$ Mathews v Diaz, 426 US 67, 82 (1976).
} 
for nonconstitutional institutional reasons. ${ }^{132}$ In either case, institutional deference signals the existence of what Professor Sager has termed an "underenforced constitutional norm." 133

Much of the scholarship in the immigration field has seen in the modern cases (regrettable) declarations of substantive constitutional law. ${ }^{134}$ To some extent the characterization of the cases as substantive norm decisions may be part of a strategic effort to persuade the courts to abandon the substantive double standard: the idea that the Constitution would not condemn, say, race-based exclusion laws seems so foreign to modern constitutionalism that to assert that the doctrine does so is to undermine it. This reading of the cases finds footing in some of the rather extreme language that the Court has used over the years. What, after all, does one make of the statements that "[w]hatever the procedure authorized by Congress is, it is due process as far as an alien denied entry is concerned," 135 and "an alien seeking initial admission to the United States requests a privilege and has no constitutional rights regarding his application"? ${ }^{136}$ The substantive norm interpretation

${ }^{132} \mathrm{~A}$ mixture of constitutional and prudential considerations is well known in standing doctrine. See Valley Forge Christian College $v$ Americans United for Separation of Church and State, 454 US 464, 471-76 (1982).

${ }^{133}$ Lawrence G. Sager, Fair Measure: The Legal Status of Underenforced Constitutional Norms, 91 Harv L Rev 1212, 1218-20 (1978).

${ }^{134}$ For example, Charles Gordon, The Alien and the Constitution, 9 Cal W L Rev 1, 2037 (1972); Louis Henkin, The Court and United States Sovereignty: A Century of Chinese Exclusion and Its Progeny, 100 Harv L Rev 853, 858-63 (1987); Michael Scaperlanda, Polishing the Tarnished Golden Door, 1993 Wis L Rev 965; Linda Kelly, Preserving the Fundamental Right to Family Unity: Championing Notions of Social Contract and Community Ties in the Battle of Plenary Power versus Aliens' Rights, 41 Vill L Rev 725, 733-38 (1996); Frank Wu, The Limits of Borders: A Moderate Proposal for Immigration Reform, 7 Stan L \& Policy Rev 35, 43-46 (1996); Note, Personbood Under the Due Process Clause: A Constitutional Analysis of the Illegal Immigration Reform and Immigrant Responsibility Act of 1996, 83 Cornell L Rev 820, 828-32 (1998). One author of this article has, on occasion, succumbed to this characterization of the cases. See T. Alexander Aleinikoff, Federal Regulation of Aliens and the Constitution, 83 Am J Intl L 862, 864 (1989) (constitutional norm applied to admission and exclusion powers holds that "as to matters relating to admission and expulsion, Congress possess[es] 'plenary' power virtually unfettered by the Constitution"). See also Stephen Legomsky, Immigration and the 7udiciary (cited in note 119) (compare 178, 190-91 with 308, 313) (plenary power doctrine described in both substantive norm and institutional deference terms).

We think Gerald Neuman gets it right in concluding that the "more enduring legacy" of the Chinese Exclusion Case is not that aliens do not possess rights, but rather that the courts should be wary of enforcing them. Gerald Neuman, Strangers to the Constitution at 134 (cited in note 119).

${ }^{135}$ United States ex rel Knauff $v$ Shaughnessy, 338 US 537, 544 (1950). See Shaughnessy $v$ United States ex rel Mezei, 345 US 206, 212 (1953).

${ }^{136}$ Landon v Plasencia, 459 US 21, 32 (1982). 
has also been aided by an obiter dictum in Matbews $v$ Diaz. ${ }^{137}$ In the course of noting that the Constitution does not automatically condemn all distinctions between citizens and aliens-hardly a startling conclusion-Justice Stevens wrote that "[i]n the exercise of its broad power of naturalization and immigration, Congress regularly makes rules that would be unacceptable if applied to citizens." 138

But there is less to these hints than meets the eye. First, Justice Stevens's comment in Mathews has been dramatically overread in support of classifications that discriminate against aliens. ${ }^{139}$ As Justice Stevens makes clear in a sentence that follows immediately the oft-cited proposition, he is referring not to regulations that draw distinctions based on alienage but rather to Congress's power to exclude and remove aliens-a power that Congress presumably cannot exercise over citizens.

Second, the statements by the Court in the past half-century that appear to echo the "no law" position of the nineteenth century are primarily found in cases involving the rights of persons arriving at the border for the first time. ${ }^{140}$ This exception at the border has a long, if controversial, history in immigration law. It is founded on the fiction that an alien at a port of entry is not inside the territory of the United States, and therefore the Constitution does not apply. Decades of scholarship have decried the fiction. As scholars from Henry Hart to Gerald Neuman have forcefully shown, the claim that the Constitution has nothing to say when the government expels persons who are seeking to enter our territory cannot be squared with the idea of a rule of law. ${ }^{141}$ Reversal of these "no law" cases is thus long overdue. In any event, they

137426 US 67.

${ }^{138}$ Id at $79-80$.

${ }^{139}$ As it was, for example, in Fiallo, 430 US at 792.

${ }^{140}$ An exception is Justice Frankfurter's opinion for the Court in Galvan v Press, 347 US 522 (1954), which upheld retroactive application of a statute mandating the deportation of any alien who at any time after entry had been a member of the Communist Party. Justice Frankfurter's statement that the formulation of immigration policies is "entrusted exclusively to Congress," id at 531, has been undercut by subsequent Supreme Court holdings that immigration regulations are subject to (albeit limited) judicial review. Fiallo $v$ Bell, 430 US at 793 n 5, 795-96 n 6; Mathews $v$ Diaz, 426 US at 82.

${ }^{141}$ Henry M. Hart, Jr., The Power of Congress to Limit the Furisdiction of Federal Courts: An Exercise in Dialectic, 66 Harv L Rev 1362, 1389-96 (1953); Neuman, Strangers to the Constitution at $118-38$ (cited in note 119 ). 
add no obvious support to a substantive norm position with respect to aliens inside the border. ${ }^{142}$

The institutional deference reading of the Court's cases receives strong support in the one modern case in which the Court actually seeks to supply a rationale in support of low-level scrutiny. In Mathews v Diaz, Justice Stevens, writing for the Court, provided the following analysis:

For reasons long recognized as valid, the responsibility for regulating the relationship between the United States and our alien visitors has been committed to the political branches of the Federal Government. Since decisions in these matters may implicate our relations with foreign powers, and since a wide variety of classifications must be defined in light of changing political and economic circumstances, such decisions are frequently of a character more appropriate to either the Legislature or the Executive than to the Judiciary. . . . Any rule of constitutional law that would inhibit the flexibility of the political branches of government to respond to changing world conditions should be adopted only with the greatest caution. The reasons that preclude judicial review of political questions also dictate a narrow standard of review of decisions made by Congress or the President in the area of immigration and naturalization. ${ }^{143}$

The language here is not of a separate set of substantive norms for immigration and nationality cases, but rather the need for judicial caution and attention to role. Particularly revealing is the concluding sentence's reference to the "political question" doctrinesignaling concerns of justiciability rather than the presence of an applicable (lower than normal) substantive constitutional norm. ${ }^{144}$ As the Court has noted, "[i]n invoking the political question doctrine, a court acknowledges the possibility that a constitutional provision may not be judicially enforceable. Such a decision is of course very different from determining that specific congressional action does not violate the Constitution." 145

Justice Stevens is careful to reason by analogy to the political question doctrine, rather than fully to invoke it. A conclusion that

\footnotetext{
${ }^{142}$ See Legomsky, 1984 Supreme Court Review at 276-77 (cited in note 119).

${ }^{143} 426$ US 67, 81-82 (1976) (emphasis supplied).

${ }^{144}$ See Laurence Tribe, American Constitutional Law $\$ 3-13$ (Foundation, 2d ed 1988).

${ }^{145}$ U.S. Dep't of Commerce v Montana, 503 US 442, 457 (1992) (footnotes omitted).
} 
immigration cases involve nonjusticiable political questions is not consistent with applying even a low level of scrutiny. But Justice Stevens's description of immigration and nationality policies as "decisions ... [that] may implicate our relations with foreign powers" is an obvious reference to congressional and executive branch actions that have typically been found to constitute nonjusticiable political questions. ${ }^{146}$ Reference to the political question doctrine also provides a linkage-albeit in the form of a pun-to the nineteenth-century decisions that saw immigration cases as raising "political questions." As noted above, that terminology in the early cases referred to matters of policy appropriate for congressional resolution, not to the modern political question doctrine of nonjusticiability, nor to the deferential standard of review applied in the modern plenary power cases. But Justice Stevens makes the most of the play on words, using the word "political" four times in the quoted paragraph. ${ }^{147}$ Thus, the Court in Matbews based the application of low-level scrutiny on an understanding of the appropriate role of the courts, invoking the spirit but not the full force of both the nineteenth-century cases and the modern political question doctrine in crafting a rule of institutional deference.

To be sure, the cases are not examples of ringing clarity on the question of the source of low-level scrutiny. Fiallo, for instance, is a muddle of quotations from the old ("no law") cases, references to the "political character" of the immigration power, citations to Mathews and other modern deference cases, and a concluding quo-

\footnotetext{
${ }^{146}$ See Baker v Carr, 369 US 186, 211-13 (1962). This connection is made even clearer in an earlier opinion, Harisiades $v$ Sbaughnessy, 342 US 580. There the Court upheld a statute mandating the deportation of persons who had been members of the Communist Party. Justice Jackson, writing for the majority, stated: "[A]ny policy toward aliens is vitally and intricately interwoven with contemporaneous policies in regard to the conduct of foreign relations, the war power, and the maintenance of a republican form of government." Id at 588-89. These references invoked subject areas that had been ruled political questions in the past. See, for example, Oetjen v Central Leather Co., 246 US 297, 302 (1918) (recognition of a foreign government); Commercial Trust v Miller, 262 US 51, 57 (1923) (cessation of hostilities); Luther $v$ Borden, 48 US (7 How.) 1 (1849) (Guaranty Clause). They thus offered support for Justice Jackson's conclusion that "[s]uch matters are so exclusively entrusted to the political branches of government as to be largely immune from judicial inquiry or interference." Interestingly, despite this "no law" sounding language, Justice Jackson examined the deportation ground under prevailing First Amendment doctrine that the Court applied to domestic legislation. See Harisiades, 342 US at 592; Aleinikoff, $83 \mathrm{Am} \mathrm{J}$ Intl $\mathrm{L}$ at 868-69 (cited in note 134).
}

${ }^{147}$ See text at note 143 . 
tation from Justice Frankfurter that immigration matters are "solely for the responsibility of the Congress and wholly outside the power of this Court to control." ${ }^{148}$ With this kind of ordnance, the result in the case is, so to speak, overdetermined. And Matbews itself can be read as a substantive norm case, despite the Court's invocation of a quasi-political question doctrine. There the Court held that the rule of strict scrutiny for state laws that deny welfare benefits on the basis of alienage is not applicable to federal laws that do the same. One might see in Matbews, then, the application of a substantive norm that regulations disfavoring aliens, when adopted by Congress, are not unconstitutional when viewed as an exercise of the immigration power. On this reading, the Court has not refused for prudential reasons to apply the usual nondiscrimination norm; it has crafted a different (fully enforced) nondiscrimination norm for federal laws. ${ }^{149}$

In the end we find the institutional deference reading more persuasive. One can make the decisions fit the substantive law position, but it does not seem to get to the core of the cases. The Court never purports to identify a different substantive norm in immigration cases. Consider Fiallo. At issue in the case was a provision in the immigration code that permitted out-of-wedlock children to enter the United States based on a relationship with a U.S. citizen or permanent resident alien mother but not a U.S. citizen or permanent resident alien father. The plaintiffs argued that the "double-barreled discrimination" (sex and illegitimacy) rendered the statute plainly unconstitutional under prevailing law. A majority of the Justices disagreed. The Court adopted a standard of virtual judicial abdication-that the statute will be sustained if based on a "facially legitimate and bona fide reason." 150 But it did not do so by announcing a substantive norm for immigration cases; it did not make arguments that discrimination on these bases was less offensive in the immigration area, that immigrants may not

\footnotetext{
148430 US at 792-96. The Court does not indicate that the Frankfurter quotation, taken from Harisiades $v$ Shaugbnessy, is located in a concurring opinion. 342 US at 597 (Frankfurter concurring).

${ }^{149}$ Mathews can, with equal plausibility, be read as consistent with the institutional deference position: the reasons that caution against judicial intervention in immigration regulations apply in cases of federal regulation; but because the immigration power is exclusively federal, no similar deference is warranted in cases involving state regulation of aliens.

${ }^{150} 430$ US at $794-95$.
} 
invoke equal protection principles, or that those principles must be differently interpreted when applied to immigrants. Instead, the Court reiterated several times that it had "no judicial authority to substitute our political judgment for that of the Congress." "To us, this is the language of institutional deference amounting to underenforcement, not the rendering of a substantive judgment on the meaning of equal protection in immigration cases. ${ }^{152}$

How the plenary power doctrine is understood has important implications for all three branches of government. If the plenary power cases are examples of underenforced constitutional norms, then Congress and the executive have a constitutional duty to take the norms seriously in writing and implementing immigration and nationality statutes. ${ }^{153}$ Furthermore, as we argue immediately below, a majority of the Justices in Miller implicitly concluded that institutional reasons do not foreclose full constitutional scrutiny of sex-based nationality statutes - that is, statutes providing for the granting of citizenship. Thus, Miller moves nationality cases from an underenforced to an enforced norm category. It therefore necessitates a shift in the approaches of lower courts to such cases.

\section{B. MILLER V ALBRIGHT: UNDERCUTTING UNDERENFORCEMENT}

The underenforced norm reading is the best interpretation of the pre-Miller precedent. But Miller, we believe, has fundamentally changed the rules, as much by what it did not say as by what it did. As we noted, the court of appeals opinions and the parties' briefs were largely about Fiallo. Indeed, Judge Wald "regretfully" concurred in the panel's decision based on her belief that Fiallo "foreclose[d]" a conclusion that the statute was unconstitutional. ${ }^{154}$ If the Supreme Court had been of the same view, then its opinion would have been short and simple. Indeed, there would have been

\footnotetext{
${ }^{151}$ Id at 798.

${ }^{152}$ A conclusion that the immigration cases embody the substantive norm position would put the burden on the government to provide a substantive theory as to why such regulations are subject to an exceedingly low standard of review. For persuasive analysis and rejection of such substantive theories, see Neuman, Strangers to the Constitution, ch 7 (cited in note 119) and Legomsky, 1984 Supreme Court Review at 260-78 (cited in note 119).

${ }^{153}$ See Sager, 91 Harv L Rev at 1227 (cited in note 133).

${ }^{154} 96 \mathrm{~F} 3 \mathrm{~d}$ at 1473 (Wald concurring).
} 
little reason for the Court to take the case for review if it thought that it clearly fell within the ambit of Fiallo.

But opinions in Miller representing a majority of the Justices read like sex discrimination opinions, not like the usual opinions in immigration cases. Other than in Justice Scalia's opinion, we do not find the paragraphs that typically begin immigration and naturalization cases, reciting the cases establishing plenary congressional power and mandating judicial deference. Justice Stevens's opinion (joined by the Chief Justice) includes a passing reference to Mathews $v$ Diaz in a footnote, ${ }^{155}$ but the style and tenor of his text are far more consistent with his opinions in sex discrimination cases than in immigration cases. ${ }^{156}$ And the opinions of Justices Breyer and Ginsburg (both joined by Justice Souter) show no sign of deference based on subject matter. In short, Miller (but for the justiciability obstacles) is a case of full enforcement of a constitutional norm. While the Justices disagreed over whether the statute passes scrutiny under the test usually applied in sex discrimination cases (and whether that claim is properly before the Court), there is little doubt that a majority believed that the statute ought to be judged under the usual sex discrimination standard. The case is therefore of singular importance for the field of nationality law.

There is language in several of the opinions that might suggest that the Court's new-found willingness to apply usual constitutional norms begins and ends with citizenship statutes. Justice Breyer's three-Justice dissenting opinion purported to distinguish citizenship-at-birth cases from immigration and naturalization cases. Statutes that confer citizenship at birth, he wrote, "do not involve the transfer of loyalties that underlies the naturalization of aliens, where precedent sets a more lenient standard of review. See Fiallo $v$ Bell[.]" ${ }^{157}$ Justice Stevens, while putting aside the question

${ }^{155} 118 \mathrm{~S}$ Ct at $1437 \mathrm{n} 11$ (Stevens opinion).

${ }^{156}$ Compare the opinions Justice Stevens wrote for the Court in Lebr v Robertson, 463 US 248 (1983), and Matbews v Diaz, 426 US 67 (1976).

${ }^{157} 118 \mathrm{~S} \mathrm{Ct}$ at 1458 (Breyer dissenting). Bryer later noted:

In sum, the statutes that automatically transfer American citizenship from parent to child "at birth" differ significantly from those that confer citizenship on those who originally owed loyalty to a different nation. To fail to recognize this difference, and consequently to apply an unusually lenient constitutional standard of review here, could deprive the children of millions of Americans, married and unmarried, working abroad, traveling, say, even temporarily to Canada or Mexico, of the most basic kind of constitutional protection.

ld at 1460 . 
whether Fiallo "dictates the outcome of this case," distinguished Fiallo as involving "the claims of several aliens to a special immigration preference, whereas here the petitioner claims that she is, and for years has been, an American citizen." ${ }^{58}$ And Justice Scalia's opinion applied the policy of deference to the statute in Miller; a fortiori, he is unlikely to apply any higher level of scrutiny to immigration cases.

Thus, a surface reading of the opinions cuts against the idea that Miller signaled a shift in immigration jurisprudence generally, as opposed to citizenship cases alone. ${ }^{159}$ But it is not obvious that Miller can be so easily limited to nationality cases. The question is whether the line drawn between citizenship-at-birth cases (such as Miller) and immigration and naturalization cases (such as Fiallo) can be sustained.

The Constitution, of course, provides citizenship at birth only to persons born in the United States. It says nothing explicit about the power of Congress to provide citizenship jure sanguinis (by bloodline) to persons born overseas. In confronting this conundrum, the Court has determined that such statutes must be exercises of the naturalization power. ${ }^{160}$ This conclusion finds support in the first federal citizenship statute, adopted in 1790. Entitled "An Act to establish an uniform Rule of Naturalization," its single section provided qualifications for admission to citizenship of aliens residing inside the United States and for the birthright citizenship of children born to U.S. citizen fathers outside the United States. ${ }^{161}$ Thus, citizenship by descent- "not covered by the Fourteenth Amendment" and "necessarily left to proper congressional action" 162 -is bestowed only upon those who meet specific statutory requirements. In this way it bears a closer resemblance to

\footnotetext{
${ }^{158} 118 \mathrm{~S} \mathrm{Ct}$ at 1434 (Stevens opinion).

${ }^{159}$ It is noteworthy, however, that the Justices failed to respond to Judge Wald's opinion below urging the Court to reconsider Fiallo. 96 F3d at 1477 (Wald concurring). Had they sought to draw a sharp line hetween citizensbip and immigration cases they could have done so by expressly affirming Fiallo. Such language would deter other lower court judges from sending the Court pointed invitations to overturn its precedents. But the Court didn't do so. The Justices simply put Fiallo to one side.

${ }^{160}$ Rogers $v$ Bellei, 401 US 815, 830 (1971), quoting United States v Wong Kim Ark, 169 US 649, 688 (1898).

${ }^{161}$ Act of March 26, 1790, $\$ 1,1$ Stat 103. Today, the immigration code does not categorize citizenship by descent as a form of naturalization. See note 168 .

${ }^{162}$ Rogers, 401 US at 830.
} 
other membership decisions established by statute-naturalization and admission as an immigrant - than to the automatic conferral of citizenship by birth in the United States.

In these three statutory areas-citizenship by descent, naturalization, and immigration-the Court has recognized Congress's broad power to establish categories and prerequisites. To our shame, racial and gender classifications have littered these areas of regulation since the earliest days of the nation. ${ }^{163}$ No Supreme Court case (prior to the opinions in Miller) had suggested that classifications permitted in one area would be unacceptable in the others; and no Supreme Court case has ever invalidated such a classification. It is therefore not surprising that the court of appeals in Miller concluded, ${ }^{164}$ and the government's brief to the Supreme Court asserted, ${ }^{165}$ that the plenary power doctrine of the immigration cases applied in similar fashion to challenges to jus sanguinis statutes.

Citizenship by birth in the territory of the United States has generally been viewed in a different light. The Fourteenth Amendment fixed jus soli citizenship in the Constitution, to make permanent the rejection of Justice Taney's opinion in Dred Scott. The power of the principle was affirmed by the Court's striking decision in United States $v$ Wong Kim Ark, ${ }^{166}$ which held that children born in the United States to Chinese immigrant parents were citizens at birth-even though federal law prohibited their parents from seeking or obtaining naturalization.

History and precedent have thus tended to place constitutional membership decisions in one category and congressional membership decisions in another. ${ }^{167}$ This schema puts jus soli citizenship

${ }^{163}$ See Act of March 26, 1790, $§ 1,1$ Stat 103 (limiting jus sanguinis citizenship to the children of U.S. citizen fathers; restricting naturalization to "free white" persons). Racial bars to naturalization were not fully extirpated until 1952. See Ian F. Haney López, Wbite by Law: The Legal Construction of Race 42-47 (NYU, 1996). The first major federal immigration statutes provided for tbe exclusion of Chinese. Act of May 6, 1882, ch 126, 22 Stat 58.

$16496 \mathrm{~F} 3 \mathrm{~d}$ at $1470-71$.

${ }^{165} \mathrm{Br}$ for Resp 21-23.

166169 US 649 (1898).

${ }^{167}$ Rogers $v$ Bellei, 401 US 815 (1971), should be considered in this light. The case considered the constitutionality of the (now repealed) requirement that jus sanguinis citizens born abroad take up residence in the United States for five years between the ages of fourteen and twenty-eight in order to preserve their citizenship. Under the statutory scheme, a child was held to be a citizen at birth, but was deemed to lose his or her citizenship if the residency requirement was not met in time. The dissenting Justices analogized the operation 
in one category, while jus sanguinis citizenship, naturalization, and immigration are placed in another. If Miller is read as fully enforcing constitutional norms for jus sanguinis citizenship, then arguably the conceptual categories have shifted. This is the explicit project of Justice Breyer's dissent, which weit to lengths to explain why both varieties of birthright citizenship-jus soli and jus sanguinisfit under the full enforcement rubric, while naturalization and immigration regulations do not. ${ }^{168}$ Under this reformulated schema, one category encompasses citizens-at-birth (both constitutional and statutory); the other includes citizens-by-naturalization and immigrants (exclusively statutory).

Can this classification be sustained? Or does shifting the statutory benefit of jus sanguinis citizenship into the fully enforced norms category tend to bring along other statutory benefits in the immigration and citizenship field?

One argument for separating birthright citizenship from naturalization and immigration might arise from the strong preference, in international and domestic law, for avoiding statelessness. ${ }^{169}$ On this account, denying birthright citizenship in situations that can occasion statelessness is more troubling than denying naturalization or an immigration status because one may assume that persons in the latter two categories have a preexisting citizenship to fall back on. Justice Breyer signaled this concern when he noted that under discriminatory jus sanguinis rules "many . . . children, lacking

of the condition subsequent to a deprivation of citizenship, which would have triggered the strict rules of Afroyim v Rusk, 387 US 253 (1967) (permitting loss of citizenship only if citizen affirmatively intended to relinquish it). But the majority had little trouble sustaining the challenged provision, finding that it was a reasonable way to deal with problems of dual nationality. 401 US at 831-36. The holding in Bellei does not coincide exactly with the constitutional/statutory line described in text because the rule of Afroyim would apply to naturalized as well as birthright citizenship. But the ease with which the Court sustained the condition subsequent demonstrates its view that congressional decisions regulating the acquisition of citizenship jure sanguinis are largely free from judicial restraint.

${ }^{168} 118 \mathrm{~S} \mathrm{Ct}$ at 1458-60 (Breyer dissenting). Breyer quoted a provision of the INA that supports this distinction. Id at 1460 . The statute defines "naturalization" as "the conferring of nationality of a state upon a person after birth, by any means whatsoever," INA $\$ 101($ a)(23), 8 USC $\$ 1101($ a)(23), thereby separating jus sanguinis birthright citizenship from naturalization (and immigration) regulations. But this statutory line is surely not determinative of the constitutional issue.

${ }^{169}$ As we note in text at notes 14-15, concerns about statelessness may account in part for the sex-based distinction in the statute under challenge in Miller. We argue here that the issue of statelessness does not justify applying constitutional standards to immigration statutes that are different from those that are applied to citizenship statntes. 
citizenship, would be placed outside the domain of basic constitutional protections." 170

This is a legitimate concern, but one with little purchase in today's world. Lorelyn Miller is unlikely to be born stateless if she is born in the country of which her mother is a citizen; and even if she were born outside her mother's country of citizenship, she would not be stateless unless that country had a rule that barred transmission of citizenship jure sanguinis in such a case and the country in which she is born is not a jus soli state. This result was far more likely in earlier days when citizenship was largely transmitted by the father. ${ }^{171}$ But virtually everywhere today birth to a mother in her home country transmits citizenship; and most states permit transmission of the mother's citizenship even when the birth occurs outside the mother's state of citizenship.

Perhaps Justice Breyer's concern was not so much statelessness as a child's lack of U.S. citizenship (whether or not he or she has citizenship in another country). The Court has frequently noted the extraordinary value placed on U.S. citizenship, describing it as "a most precious right" regarded by many as "the highest hope of civilized men." 172 A desire to avoid discriminatory distribution of such a highly valued right (and the opportunities that accompany it) might be seen as justification for placing birthright citizenship in a class by itself. But if it is the significance of U.S. citizenship that triggers full enforcement of constitutional norms, then it is hard to see why naturalization regulations would be left on the other side of the line.

Justice Breyer sought to distinguish naturalization from jus sanguinis citizenship by noting that naturalization involves "a transfer of loyalties" rather than acquisition of a status at birth. ${ }^{173}$ But the significance of that distinction is unclear, and he did not elaborate on it. Perhaps it is intended to signal the nature and depth of a citizen's attachment to the United States: for birthright citizens,

\footnotetext{
${ }^{170} 118 \mathrm{~S} \mathrm{Ct}$ at 1458 (Breyer dissenting).

171 These are the statutes and practices referred to in Justice Ginsburg's dissent. $118 \mathrm{~S}$ Ct at $1450-53$.

${ }_{172}$ Kennedy v Mendoza-Martinez, 372 US 144, 159 (1963); Scbneiderman v United States, 320 US 118, 122 (1943).

${ }^{173} 118 \mathrm{~S} \mathrm{Ct}$ at 1458 (Breyer dissenting).
} 
U.S. nationality may be a core aspect of identity whose nonrecognition or deprivation may inflict serious harm. This characterization may well be accurate for persons born in the United States or for children born to U.S. citizens who are traveling abroad. ${ }^{174}$ But it is not necessarily an apt description of all jus sanguinis citizens. Under the law, citizenship by descent may be asserted by someone who has never resided in the United States nor resided with a U.S. citizen until almost the age of majority. To be eligible for naturalization, however, an immigrant usually must have been residing in the United States as a lawful permanent resident for at least five years. ${ }^{175}$ At the time of naturalization, most aliens are fully-functioning members of U.S. society. From this perspective, the naturalizing citizen is likely to be as much a part of the American polity as the person asserting birthright citizenship from abroad. ${ }^{176}$

Consideration of the importance of U.S. citizenship, then, may nudge naturalization into the same category as birthright citizenship. But such reasons do not obviously reach immigration regulations. On what basis, then, might it be argued that Miller's reasoning casts a shadow on Fiallo? Curiously enough, Justice Stevens's opinion provides grounds for thinking that it might. Although, as noted above, Justice Stevens purported to distinguish Fiallo as involving "a special immigration preference" rather than a claim to U.S. citizenship, ${ }^{177}$ he later seemed to undo the distinction in a footnote:

Though petitioner claims to be a citizen from birth, rather than claiming an immigration preference, citizenship does not pass by descent. . . . Thus she must still meet the statutory requirements set by Congress for citizenship. . . . Deference to the political branches dictates "a narrow standard of review

\footnotetext{
${ }^{174}$ Id at 1460.

${ }^{175}$ INA $\$ 316(a), 8$ USC $\$ 1427$ (a). Spouses of U.S. citizens may naturalize after three years' residence. INA $\$ 319(a), 8$ USC $\$ 1430(a)$.

${ }^{176}$ Interestingly, although we usually think of the Fourteenth Amendment as affirming the principle of jus soli, it in fact recognizes the citizenship of "persons born or naturalized in the United States." The Amendment, as noted, is silent as to citizenship by descent. In Rogers $v$ Bellei, Justice Black's dissent argued that jus sanguinis citizens come within the protection of the Fourteenth Amendment because the Amendment's coverage of persons "naturalized in the United States" should be read to mean "naturalized into" the United States. 401 US at 839-43 (Black dissenting).

${ }^{177}$ Id at 1434 (Stevens opinion).
} 
of decisions made by the Congress or the President in the area of immigration and naturalization." Mathezws $v$ Diaz[.] $]^{178}$

The footnote successfully answered Breyer's analysis: jus sanguinis citizenship and immigration classifications are creatures of federal statute. But the footnote equally undermined Justice Stevens's attempt to put Fiallo aside. Citizenship-at-birth for some children born overseas is as much a "special ... preference" as immigration for some classes of children.

It may be hard to see these kinds of citizenship decisions as pretty much the same as immigration decisions. Our usual mental image of the immigration process is of an alien arriving on our shore, attaining full membership after a number of years, and thereby bestowing American citizenship on his or her children and subsequent generations. From this perspective, there appears to be a significant difference between immigration and citizenship; it is the distinction we draw between probationary and tenured workers, between guests and members of the family.

But the rules and practices that define the American system of membership do not map on to this "straight-line model." Immigration, naturalization, and birthright citizenship provide overlapping, sometimes anomalous, modes of access to membership. For example, while the straight-line model is likely to view membership decisions as the province of full members, the combination of the $j u s$ soli principle and immigration means that nonmembers can "create" full members (by having children in the United States). And while the straight-line model might suppose that jus sanguinis citizenship would be recognized at birth, with the child living in an "American" home (even if overseas), in fact such citizenship may be asserted long after birth by a person who has established relatively few ties to this country. In such cases, the recognition of U.S. citizenship may serve as an efficient method of acquiring residence in the United States-rather more akin to admission as an immigrant than to the affirmation of a long-standing sense of identity.

Finally, it is important to see that immigration classifications do more than decide which persons living beyond our borders shall be invited to join us as "guests." Because a large number of immi-

${ }^{178} \mathrm{Id}$ at $\mathrm{I} 436 \mathrm{n} 11$. 
grants are granted permanent resident status based on their relationship to a U.S. citizen, ${ }^{179}$ such classifications necessarily draw lines among full members. ${ }^{180}$ Justice Marshall made this discrimination among U.S. citizens the focal point of his dissent in Fiallo ${ }^{181}$ Justice Powell's response, relegated to a footnote in the majority opinion, avoids rather than answers the argument. While accepting Justice Marshall's reasoning as "facially plausible," Justice Powell asserted that its "fallacy ... is rooted deeply in the fundamental principles of sovereiguty." 182 But why the plenary power cases should be read to justify discrimination among citizens is never explained.

In sum, despite our intuition that birthright citizenship is qualitatively different from naturalization or admission as an immigrant, it is difficult to construct a persuasive case for limiting the application of usual constitutional norms solely to jus sanguinis statutes. Upon reflection, perhaps this should not surprise us. The Constitution is a document fundamentally concerned with creating and limiting the powers of government, not on behalf of citizens, but on behalf of persons. ${ }^{183}$ Importantly, this is not to say that for all purposes aliens and citizens are entitled to similar treatment. The point is that the usual constitutional norms are not suspended for immigration regulations, even if these norms tolerate differences

${ }^{179}$ In fiscal year 1996, 52 percent of the 787,335 immigrants admitted to the United States for permanent residence entered on the basis of a close family relationship with a U.S. citizen. (These numbers do not include persons who entered the United States as refugees or were granted political asylum here.) U.S. Dept of Justice, INS, 1996 Statistical Yearbook of the Immigration and Naturalization Service, table B (Oct 1997).

${ }^{180}$ See Wu, 7 Stan L \& Policy Rev at 49-50 (cited in note 134); Kelly, 41 Vill L Rev at 778-80 (cited in note 134). See also Hiroshi Motomura, Whose Immigration Law? Citizens, Aliens, and the Constitution, 97 Colum L Rev 1567, 1582-83 (1997) (reviewing Gerald Neuman, Strangers to the Constitution); Hiroshi Motomura, Whose Alien Nation? Two Models of Constitutional Immigration Law, 94 Mich L Rev 1927, 1942-52 (1996) (reviewing Peter Brimelow, Alien Nation).

The Court seems to have understood this relationship of sponsor to beneficiary in Miller. Irrespective of its ruling as to Lorelyn Miller's standing, the Justices agreed that Charlie Miller-had he remained a party - could have contested the differential treatment accorded U.S. citizen mothers and fathers who sought to confer citizenship on out-of-wedlock children. Indeed, Justice O'Connor thought that Mr. Miller was the only person who had standing to assert the constitutionality of the sex-based classification in the statute. $118 \mathrm{~S}$ Ct at 1442-43 (O'Connor concurring). Immigration laws that create classes of U.S. citizens entitled to sponsor close family members should similarly be seen from the perspective of the sponsoring citizen as well as the would-be immigrant.

181430 US 787, 806-09 (Marshall dissenting).

${ }^{182}$ Id at 795-96 n 6. See Wu, 7 Stan L \& Policy Rev at 45-46 (cited in note 134).

${ }^{183}$ See Alexander M. Bickel, The Morality of Consent ch 2 (Yale, 1975). 
between citizens and aliens. For example, there is general agreement that U.S. citizens may not be banished or exiled; yet no one doubts the existence of a federal deportation power. So, too, procedural due process norms may call for different procedures for adjudicating claims to citizenship than claims to immigrant status. ${ }^{184}$ But these differences in treatment do not turn on the nonapplication of norms to immigration decisions. Rather, they turn on differential explication of existing norms based on criteria relevant to the norms. For example, in determining what process is due under the Fifth Amendment, the prevailing analysis looks to the individual's stake in the proper outcome of an adjudication ${ }^{185}$ - a test that might well place more value on citizenship claims than claims to enter as an immigrant. Thus, a conclusion that immigration regulations are not immune from usual constitutional norms does not mean that we cannot continue to place a high value on U.S. citizenship.

\section{THE COLLAPSE OF INSTITUTIONAL DEFERENCE}

AND THE ECLIPSE OF PLENARY POWER

We have argued that Miller's full enforcement of constitutional norms cannot easily be limited to citizenship-by-descent statutes. But this gets us only halfway to full enforcement in naturalization and immigration cases. Because underenforcement is a function of the inappropriateness of judicial intervention, we must consider whether there might be grounds for institutional deference in the immigration area-even if the Court has cast them aside for citizenship statutes. We conclude that the reasons usually offered for deference in immigration and nationality cases appear quite weak after Miller.

We have noted above that the Court has explained its stance of deference in quasi-political-question terms. ${ }^{186}$ But, as others have shown, ${ }^{187}$ it takes little more than a glance at the Baker $v$ Carr factors $^{188}$ to recognize their inapplicability to most constitutional

\footnotetext{
${ }^{184}$ See INA $\$ 242(\mathrm{~b})(5),(7)(B), 8$ USC $\$ 1252(\mathrm{~b})(5)$, (7)(B) (special procedures for determinations of claims to U.S. nationality that arise in the course of a removal proceeding).

${ }^{185}$ Mathews v Eldridge, 424 US 319 (1976).

${ }^{186}$ See text at notes $130-52$.

${ }^{187}$ We make the arguments in this section cursory because they have received full and persuasive treatment in Neuman, Strangers to the Constitution, ch 7 (cited in note 119) and Legomsky, 1984 Supreme Court Review at 261-69 (cited in note 119).

${ }^{188} 369$ US 186, 217 (1962).
} 
questions involving immigration and naturalization. These areas of federal power are no more or less demonstrably committed to another branch than other federal powers such as the commerce or tax and spending powers. (Indeed, the immigration power is not specifically mentioned anywhere in the Constitution.) When the challenges are based on the Due Process and Equal Protection Clauses (as most are), there is no basis for finding a lack of judicially discoverable or manageable standards; these are mainstays of modern constitutional law. Nor it is likely that a court decision invalidating an immigration or naturalization classification or procedure would "express a lack of respect due coordinate branches" or unduly create "the potentiality of embarrassment from multifarious pronouncements by various departments on one question" 189 - at least no more than a holding that an exercise of the commerce power exceeds Congress's authority. ${ }^{190}$

Immigration regulations are frequently said to implicate the foreign relations of the United States-an area courts have largely left to the political branches. But Baker $v$ Carr properly notes that "it is error to suppose that every case or controversy which touches foreign relations lies beyond judicial cognizance." 191 As Professor Legomsky has sensibly suggested, nothing would prevent the court from staying its hand in a case that truly called for application of the political question doctrine ${ }^{192}$ - for example, a declaration by the President barring entry to the United States of citizens of a country with which the United States is at war. ${ }^{193}$

A variant of the quasi-political-question ground for institutional deference focuses on the nature of immigration and nationality regulations as "membership decisions." As the government argued in its brief to the Court in Miller:

$[\mathrm{P}]$ olicies toward the admission to this country, and most especially to full citizenship therein, of those not born here are uniquely political in character, dealing as they do with the threshold question of who is entitled to any share in the bene-

\footnotetext{
${ }^{189} \mathrm{Id}$.

${ }^{190}$ See United States v Lopez, 115 S Ct 1624 (1995).

${ }^{191} 369$ US at 211.

${ }^{192}$ Legomsky, 1984 Supreme Court Review at 268-69 (cited in note 119).

${ }^{193}$ See INA $\$ 212(\mathrm{f}), 8$ USC $\$ 1182(\mathrm{f})$ (authorizing President to suspend entry of classes of aliens whose admission would be "detrimental to the interests of the United States").
} 
fits, protections, and responsibilities of the democratic compact that the Constitution represents. ${ }^{194}$

Michael Walzer has similarly argued that admission policies "suggest the deepest meaning of self-determination," helping to constitute "historically stable, ongoing associations of men and women with some special commitment to one another and some special sense of their common life." 195 To some degree, these statements are true-although in the American context appeals to deep notions of membership have as frequently accompanied racist and nativist policies as they have policies of inclusiveness and tolerance. ${ }^{196}$ But more often the classification of aliens and the establishment of procedures for their entry and removal constitute decisions that are grounded in everyday judgments about family ties, efficiency, fraud- and crime-prevention, and economic impact. To be sure, such policies have important social, economic, and political consequences for the United States. But so do a host of other federal regulations that the Court would not hesitate to analyze under prevailing constitutional norms. ${ }^{197}$

Miller's application of usual constitutional norms to such decisions is therefore less remarkable than we might initially suppose. But what is remarkable about Miller is that the norms are applied to the set of membership decisions-citizenship rules-that arguably call for the greatest degree of institutional deference. The endowment of citizenship is how the United States creates full members, entitled-at least in theory - to the full array of rights and opportunities possessed by other citizens and entitled to participate in the governing of the state. From an institutional deference perspective, then, one might imagine that the Court would be more hesitant to intervene in decisions granting full membership rights than in decisions regulating temporary access to U.S. soil. On this account, Miller and Fiallo are a curious pair of cases. The Court has fully enforced a norm in an area likely to be

\footnotetext{
${ }^{194} \mathrm{Br}$ for Resp 22.

${ }^{195}$ Michael Walzer, Spheres of 7ustice: A Defense of Pluralism and Equality 62 (Basic Books, 1983).

${ }^{10 \%}$ See Rogers M. Smith, Civic Ideals: Conflicting Visions of Citizenship in U.S. History (Yale, 1997).

${ }^{197}$ See T. Alexander Aleinikoff, Citizens, Aliens, Membership and the Constitution, 7 Const Comm 9, 32-34 (1990).
} 
deemed more fundamental by the political branches. Once that bridge has been crossed, arguments for deference to immigration decisions seem much harder to sustain. ${ }^{198}$

The Court already knows that the government can live with constitutional scrutiny in the immigration field. For nearly a century it has applied due process norms to procedures for the removal of aliens within the United States. ${ }^{199}$ There is no evidence that these rulings have unduly hobbled federal efforts at enforcement of the immigration laws. This point may be generalized. It seems clear that rejecting the plenary power doctrine will not leave the United States weak, unprotected, or vulnerable. In Miller, a holding that the citizenship statute violated the Constitution would not have injured relations with the Philippines, harmed the U.S. economy, or placed the United States in a disadvantageous position on the world stage. And none of the various opinions in Miller made even a gesture at suggesting that dire consequences would flow from a decision in Miller's favor. Indeed, some might say that it would make this country stronger by showing to the world a nation willing to take its most fundamental commitments seriously across the board. But for us, it is enough that the Court has shown the way in Miller: that respect for constitutional principles can and should now outweigh institutional reasons for judicial deference in immigration and citizenship matters.

In this way, Miller may well come to be seen as the Baker $v$ Carr of immigration law, rendering fully justiciable what had earlier been seen as beyond judicial competence. In the pre-Baker $v$ Carr days, it was argued that the Court's intervention in the "political thicket" 200 of reapportionment would be improvident and unwise. History now tells a different story. Democratic norms have been promoted without any diminution of respect for the Court. ${ }^{201}$ Chief among the naysayers was Felix Frankfurter, whose dissent in Baker is a monument to the perils of dire predictions. His call

\footnotetext{
${ }^{198}$ Of course, from the individual's perspective, citizenship may be viewed as a more significant benefit than a green card. But the traditional position of judicial deference flows not from the relative value placed on the benefit by the individual, but rather from institutional considerations.

${ }^{199}$ Yamataya v Fisher; 189 US 86 (1903).

${ }^{200}$ Colgrove v Green, 328 US 549, 556 (1946) (Frankfurter opinion).

${ }^{201}$ See Peter Schuck, The Thickest Thicket: Political Gerrymandering and fudicial Regulation of Politics, 87 Colum L Rev 1325, 1380-81 (1987).
} 
for judicial nonintervention in the reapportionment cases echoes his statements in the immigration cases. The utterances, which still figure prominently in the Court's decisions and in the government's briefs, seem increasingly sterile with the years. In a concurring opinion in Harisiades (which no other member of the Court joined), he declared that regulation of immigration is a matter "solely for the responsibility of the Congress and wholly outside the power of this Court to control."202 Thus, "whether immigration laws have reflected xenophobia in general or anti-Semitism or anti-Catholicism," it is up to Congress, not the courts, to correct them. ${ }^{203}$ Three years later, Justice Frankfurter wrote the majority opinion in Galvan $v$ Press, a case upholding the retroactive application of a deportation statute ordering the removal of any person who at any time had been a member of the Communist Party. Had he been "writing on a clean slate," Justice Frankfurter reported, he might have concluded that the law violated due process and the Ex Post Facto Clause. But the slate was not clean: "[ $t$ ]hat the formulation of [immigration] policies is entrusted exclusively to Congress has become about as firmly embedded in the legislative and judicial tissues of our body politic as any aspect of our government." ${ }^{204}$ These words were written in the same year that Brown $v$ Board of Education invalidated the deeply ingrained legal and social system of segregation.

The Court took the right turn in Baker $v$ Carr, laying Justice Frankfurter's rhetoric to the side. Miller shows that Justice Frankfurter's concerns in immigration and nationality cases carry little weight today. It is time to lay them to rest too.

\section{Miller and the Roles of Government Lawyers}

\section{A. THE OBLIGATIONS AND PERILS OF UNDERENFORCEMENT}

Although the Court arrived at many of the right conclusions in Miller, the case never should have reached the Court in the form in which it did. Under the underenforcement regime that was in place before Miller, the political branches have the primary respon-

\footnotetext{
${ }^{202} 342$ US at 597 (Frankfurter concurring).

${ }^{203}$ Id.

${ }^{204} 347$ US 522, 530-31 (1954).
} 
sibility for interpreting the Constitution. It appears that they did not carry out that responsibility in connection with the statute at issue in Miller. We now reexamine the political branches' approach to immigration law in that light. ${ }^{205}$

1. The obligations. The executive branch's usual approach to constitutional decision making in immigration matters is exemplified by a recent regulation establishing procedures for the detention and release of criminal aliens. ${ }^{206}$ One aspect of the regulation authorizes the United States to detain for deportation any permanent resident alien who has in the past been convicted of certain crimes, without making an individualized determination that the particular permanent resident alien poses a risk of flight or danger to the community. In describing the INS's view that such a procedure is consistent with due process, the regulation's preamble relies heavily on the plenary power doctrine. Liberally quoting from the plenary power cases, including Mathews $v$ Diaz and Fiallo $v$ Bell, the INS notes that responsibility over immigration "has been committed to the political branches of the Federal Government."207 The agency explains that, "[o]nce a facially legitimate and bona fide reason is found, courts will neither look behind the exercise of discretion, nor test it by balancing its justification against the constitutional interest asserted by those challenging the statute."208 The entire constitutional argument is framed in terms of how the courts review the political branches' treatment of aliens. The INS predicts, based on prior judicial decisions sustaining analogous immigration measures, that the courts would sustain the detention regulation against constitutional challenge. ${ }^{209}$

Our reading of the modern plenary power cases as establishing a regime of judicially underenforced constitutional norms suggests, however, that simply forecasting the Court's reaction is inadequate. If the judiciary partially suspends its own enforcement of constitutional norms (such as procedural fairness or, as in Miller,

\footnotetext{
${ }^{205}$ The following analysis uses executive-branch illustrations, but the point could be similarly developed regarding the obligations of Congress.

2068 CFR Parts 3 and 236 (1998).

${ }^{207} 63$ FR 27441, 27444 (1998).

${ }^{208}$ Id, quoting Campos v INS, 961 F2d 309, 316 (1st Cir 1992).

${ }^{209} 63 \mathrm{FR}$ at $27444-27446$.
} 
sex equality) for institutional rather than substantive reasons, ${ }^{210}$ it is inappropriate for the political branches themselves to mimic the Court's restraint for purposes of their constitutional evaluation. Doing so amounts to the kind of "circular buck-passing" that Professor David Strauss has identified. ${ }^{21}$ The current Court applies lenient review under the plenary power doctrine as a way of deferring to the political branches. The assumption behind that deference is not that the political branches will also be lenient with themselves, but that those branches require flexibility in foreign affairs that would be hampered by judicial review. If the political branches parrot the courts' lenient scrutiny, everyone has deferred to everyone else, and nobody has done the full-fledged constitutional analysis. The premise of the plenary power doctrine that the political branches will do a full constitutional review thus remains unfulfilled. In our view, institutional limits on judicial review should be irrelevant to the political branches' own constitutional calculus, since they do not share the judiciary's institutional constraints.

That understanding of the political branches' approach to their own constitutional decision making in the immigration area helps to explain how the current version of the sex-based distinctions in Section 309(a) of the INA was adopted as recently as 1986 and enforced against Charlie and Lorelyn Miller, even after the Court's latest and strongest condemnations of sex-based classifications. ${ }^{212}$ Congress has included sex-based variants of these provisions in every version of the INA since it was first enacted in $1940 .{ }^{213}$ In the early years, of course, express sex-based classifications were common, and the Court would have applied only rational-basis review to sustain them against equal protection challenges. ${ }^{214}$ The INA's

\footnotetext{
${ }^{210}$ See Sager, 91 Harv L Rev at 1213-28 (cited in note 133); Brest, The Conscientious Legislator's Guide to Constitutional Interpretation, 27 Stan L Rev 585, 589 (1975).

${ }^{211}$ Strauss, Presidential Interpretation of the Constitution, 15 Cardozo L Rev 113, 128-29 (1993).

212 The 1986 amendments added subsections 309(a)(4)(B) and 309(a)(4)(C), permitting acknowledgment or adjudication of paternity to suffice in place of legitimation, imposed the subsection 309(a)(1) requirement that paternity, but not maternity, be shown by clear and convincing proof, and added the subsection 309(a)(3) requirement that the father promise financial support until the child turns eigbteen. See Act of Nov 14, 1986, $\$ 13,100$ Stat 3657.

${ }^{213}$ See $118 \mathrm{~S} \mathrm{Ct}$ at 1453 (Ginsburg dissenting).

${ }^{214}$ See, for example, Goesart v Cleary, 335 US 464 (1948).
} 
initial different treatment of fathers and mothers probably raised no constitutional eyebrows. When the political branches as late as 1986 opted not to change course and adopt sex-neutral, rather than sex-based, provisions, they might perhaps have concluded (erroneously, we think) that the provisions would survive heightened scrutiny; but there is no suggestion in the legislative record that Congress or the executive even considered the potential unconstitutionality of the sex-based classification. ${ }^{215}$ The underenforcednorms reading of the plenary power doctrine would require, however, that the political branches do their own constitutional analysis under heightened scrutiny. ${ }^{216}$ Plenary power, on this understanding, does not give the political branches a blank check to do as they please, but leaves them with a special responsibility to comply with constitutional norms in view of a diminished judicial backstop.

Suggesting that the political branches should do a constitutional analysis, and not merely piggyback on their predictions of the courts' underenforcement, does not answer the question bow those branches should do their "own" constitutional analysis. That question cannot be answered without reference to some theory of the political branches' role in constitutional interpretation. There is, for example, a wide range of views regarding whether the political branches should consider themselves bound by Supreme Court opinions, or only by Supreme Court judgments in cases to which the government was a party, or something in between. ${ }^{217}$

Depending on the political branches' views of how much autonomy they have in interpreting the Constitution, there may be a

\footnotetext{
${ }^{215}$ See Legislative History of 1986 Amendments to the Immigration and Nationality Act, reprinted at 1986 USCCAN 6182-83 (House Report); id at 6184 (letter from James W. Dyer, Acting Assistant Secretary, Legislative and Intergovernmental Affairs, U.S. Department of State, urging enactment of the amendments). The State Department evidently requested the 1986 amendments to Section 309(a) in order to "reduce the administrative burdens involved in ascertaining paternal domiciles and keeping track of widely variant requirements for formal legitimation." See Miller, Br for Resp 20.

${ }^{216}$ To the extent that one might assume that they concluded that the amendments were constitutional under Lebr, we believe that should not have been a basis for endorsing the bill. See text at notes 111-16.

${ }^{217}$ See generally Symposium, Executive Branch Interpretation of the Law, 15 Cardozo L Rev 43-174 (1993).
} 
significant range of answers to the question of how Congress and the executive should have reviewed Section 309(a) and its amendments in a non-buck-passing manner. Adherents of the opinionsas-binding approach would insist that the political branches apply heightened equal protection scrutiny as the Court's cases have defined it. Under this approach, the political branches should have amended Section 309(a) to make it sex-neutral in order to cure its constitutional defect before it ever got to the Supreme Court in Miller. Adherents of the full-autonomy approach would consider the political branches not to be bound by the Supreme Court's sex discrimination precedents and would suggest that they be followed only insofar as the political branches find them persuasive. They thus might contend that the 1986 amendment contained no constitutional problem that needed fixing. If, for example, the political branches disagreed with the Court and believed that the Equal Protection Clause, properly understood, requires only rational-basis review of sex-based classifications across the board, ${ }^{218}$ they might for that reason, and not through any "circular buck-passing," have seen no need to amend or to refrain from enforcing Section 309(a).

We do not purport to resolve here the complex questions regarding the appropriate scope of the political branches' power to interpret the Constitution. ${ }^{219}$ What is clear, however, is that the underenforced-norms thesis requires the political branches to take the laboring oar in evaluating the constitutionality of legislation and deciding whether to enforce it. As noted above, however, there is no sign in the legislative record that the equal protection issues were considered at all. In the absence of either a persuasive analysis that Section 309(a) satisfies equal protection, or a substantive rationale for concluding that sex-based classifications are somehow more acceptable in immigration and nationality decisions than elsewhere, Congress should have replaced the different treatment of mothers and fathers in the statute with sex-neutral terms, or

\footnotetext{
${ }^{218}$ See, for example, United States v Virginia, $116 \mathrm{~S} \mathrm{Ct}$ at 2295-96 (Scalia dissenting).

${ }^{219}$ One theory that we do find persuasive is that an executive branch constitutional decision maker should regard judicial precedent in the way a sitting Supreme Court Justice would-that is, with a healthy regard for stare decisis, but with authority to stray from past decisions where reasons favoring a new constitutional interpretation outweigh stare decisis concerns. See Strauss, 15 Cardozo L Rev at 127 (cited in note 211).
} 
the President should have vetoed, or at least registered his objection to, a bill that failed to do so. ${ }^{220}$

There is a risk-which Miller illustrates-that the political branches will not remove a constitutional defect in a statute, and that the question will therefore arise for government litigators, and the Solicitor General in particular, of whether and how to defend the statute in light of the underenforced-norms thesis. That risk is enhanced if one accepts that the underenforced-norms thesis places additional responsibility on the political branches that those branches may fail to acknowledge.

Under the prevailing view of the Solicitor General's role, he should not defend a statute that is "patently unconstitutional," even if doing so requires him to confess error and forfeit a lowercourt victory. ${ }^{221}$ There is reason to construe the confession-oferror authority narrowly to guard against the temptation to make such decisions as "a form of post-enactment veto of legislation that the current administration did not like."222 Indeed, if the presumption is that the enactment of the legislation expresses the judgment of Congress and the President that it is constitutional, then the Solicitor General's ordinary role is to defend that judgment, even where he suspects the courts might properly disagree with it; thus, the burden is on the Solicitor General to explain any decision to override the political branches' constitutional judgment by declining to defend the statute. ${ }^{223}$ Generally, the Solicitor General should

${ }^{220}$ There are examples. See H. Jefferson Powell, The Province and Duty of the Political Departments, 65 U Chi L Rev 365, 383 (1998) (discussing President's public declaration that a statute excluding all HIV-positive personnel from the military was unconstitutional and should be repealed, and observing that, "[i]n evaluating the constitutionality of [the HIV military-exclusion provision], the president applied the basic norm of equal protection without the screens of deference the courts employ").

${ }^{22 !}$ Drew S. Days, In Search of the Solicitor General's Clients: A Drama with Many Characters, $83 \mathrm{Ky} \mathrm{L} \mathrm{J} \mathrm{485,} \mathrm{500,} 503$ (1995) (quoting Representation of Congress and Congressional Interests in Court: Hearings Before the Subcommittee on Separation of Powers of the Senate Committee on the Judiciary, 94th Cong, 2d Sess 9 (1975) (statement of Rex Lee); Letter from Griffin Bell to Senator Robert Byrd, at 2 (May 8, 1979) (declining to defend statute where "reasonable arguments cannot be advanced to defend the challenged statute")).

${ }^{222}$ Days, $83 \mathrm{Ky} \mathrm{L} \mathrm{J} \mathrm{at} 502$.

${ }^{223}$ See Michael McConnell, The Rule of Law and the Role of the Solicitor General, 21 Loyola L Rev 1105, 1117 (1988) (suggesting that, in evaluating the constitutionality of acts of Congress, the Solicitor General should take particular care in light of the effect of such a decision on "the scope of authority of a separate and independent branch of government"). 
largely leave to the Court the role of reviewing constitutional judgments of the political branches. ${ }^{224}$

The argument for a very narrow role for confessions of error assumes the existence of full judicial enforcement of constitutional norms. But for the same reasons that political-branch lawyers in an advisory role bear greater responsibilities in areas of judicial underenforcement, the Solicitor General should also act with greater constitutional vigilance in those areas. That need for vigilance suggests that the Solicitor General should modify that general approach in the underenforced-norms context and be more willing to acknowledge a statute's constitutional defect.

The underenforcement thesis shows, for example, that a stance typical for Solicitors General in the domestic context is inappropriate for underenforced norms: Faced with an immigration or nationality measure that the Solicitor General believes contains a constitutional defect, he must not (1) choose to defend the statute on the ground that the Court, not the Solicitor General or any other executive branch official, is the appropriate final arbiter of constitutional questions, and then (2) argue that the Court should uphold the statute under a diminished level of judicial scrutiny as a matter of deference to the political branches. ${ }^{225}$ The ordinary reasoning - that the courts, because of their relative impartiality, are in a superior position to decide constitutional issues-does not apply when, as a matter of relative institutional competence, the courts have determined that they will not fully enforce the relevant

\footnotetext{
${ }^{224}$ It may seem odd to conclude that, in a full-enforcement context, the Solicitor General should confess error only in cases in which a constitutional defect in the government's position is patent, because those are the cases in which the Court is most likely to rule against the government in any event. In borderline cases, in contrast, the Solicitor General's advocacy is more likely to tip the balance in the government's favor (and against what the Solicitor General in fact believes is the better view), but the traditional view assumes that in sucb cases the Solicitor General would forcefully argue in favor of the constitutionality of the government act. Thus, the traditional view actually may increase the risk of circular buck-passing. That view is thus justified less as a concomitant of the Solicitor General's duty to uphold the Constitution than as a reflection of his obligations as an officer of the Court not to present a frivolous argument and force an adversary to litigate where the adversary's victory is certain, especially where confessing error presumably would not adversely affect the outcome his client would expect in any event.

${ }^{225}$ See, for example, Days, The Interests of the United States, the Solicitor General and Individual Rights, 41 SLU L J 1, 7 (1996) (arguing that courts rather than the Solicitor General should decide difficult constitutional issues in immigration and military contexts, and also asserting that courts should act deferentially toward the political branches in those contexts).
} 
constitutional norms, but will leave it to the political branches to decide how best to do so. A decision to defend an apparently (but not patently) unconstitutional statute presents less risk in a fullenforcement context; the Solicitor General can assume that, if the statute is unconstitutional, the Court will so declare. In the context of judicial underenforcement, however, the same stance is another version of circular buck-passing. In Miller itself, the Solicitor General should have sought to obviate that problem by confessing error in the brief in opposition to the petition for certiorari and expressing the executive branch's intention of working with Congress to enact a sex-neutral substitute.

The Court might grant review even in the face of the Solicitor General's confession of error and then uphold the statute under plenary power deference. ${ }^{226}$ But the government's independent duties would be unaffected by such a judicial decision, and the political branches should not view it as giving the statute an imprimatur of constitutionality. Whether or not the Court reviews a statute and sustains it under the plenary power doctrine, the executive should seek to work with Congress to fix any constitutional defect to the point where it would withstand undiluted constitutional review.

2. Perils of accepting the underenforcement model. Our view-that the political branches should take greater responsibility for ensuring that immigrants' constitutional rights are protected-honors the institutional concerns that drive the plenary power doctrine but closes a troubling constitutional gap left by the political branches' current approach to constitutional review of immigration measures. It also has the potential for enriching constitutional dialogue in the immigration area by seriously involving actors other than the courts in the project of elaborating constitutional rights. $^{227}$

\footnotetext{
${ }^{226}$ If the Solicitor General confesses error, the Court can appoint an amicus to make the argument in favor of the statute's constitutionality, or Congress can persist in disagreeing with the Solicitor General and represent itself. See 2 USC 288 (1988).

${ }^{227}$ See generally Michael J. Sandel, Democracy's Discontent: America in Searcb of a Public Pbilosophy, 107-08 (Harvard, 1996) (court-centered constitutionalism has come to limit the terıns of political discourse in the United States); Thomas W. Merrill, fuclicial Opinions as Binding Law and as Explanations for 7udgments, 15 Cardozo L Rev 43, 77 (1993) ("an executive branch that grows accustomed to taking its cues from courts may lose the capacity to engage in imaginative interpretation of the sort often needed to resolve difficult problems of administration"); Robin West, Progressive and Conservative Constitutionalism, 88 Mich L Rev 641, 718 (1990) ("I]f progressives were to reorient progressive constitutional debate
} 
It may seem quixotic to ask the political branches to shoulder a greater constitutional duty to protect immigrants' individual rights. Doing so would require the political branches to act against their institutional interests, curtailing their own prerogatives in order to respect individual rights. In areas of full judicial enforcement, Congress and the executive may be relatively effective at constitutional self-restraint, but in those areas-unlike the plenary power area-they act with the knowledge that, if they overstep the Court's established constitutional bounds, the Court will correct their errors.

There is some basis for optimism. The political branches clearly have not, up to now, been recognizing their responsibilities under an underenforced-norms conception of the plenary power doctrine. It is possible that, if the courts more clearly communicated that conception, the political branches would learn that, whereas in areas of fully enforced norms they can track judicial reasoning and rely on the courts to correct their mistakes, they must reason differently in a regime of underenforcement, themselves applying heightened or strict scrutiny even where the courts would not. Government lawyers are typically highly role-sensitive, seeking to make only those decisions and exercise only those powers that come within their constitutionally and statutorily defined province. The first step, then, is to establish clearly that a different model of constitutional decision making applies under the plenary power doctrine than in contexts where rights are fully enforced by the courts. Given such a clear understanding, congressional and executive branch counsel might respond adequately to the challenge to interpret and enforce constitutional rights.

But the perils of asking the political branches to shoulder a greater constitutional duty remain, and they are substantial. Not only are there grounds for concern that the political branches, faced with scant judicial check, will take lightly any responsibility they have to protect immigrants' rights, but there is also cause to worry that general acceptance of the underenforced-norms reading of the plenary power cases would, from immigrants' perspective, actually make the situation worse. As we noted

toward legislative politics rather than adjudicative law, they would invigorate and enrich the terms and the stakes of public debate.... We have, in effect, alienated the responsibility for public morality to the courts"). 
above, some scholars have argued that the plenary power doctrine represents not mere judicial underenforcement, but a substantive lower standard applicable to immigration claims. We reject that view as inconsistent with the cases' language, and as unsupported by the kind of logic that such a reading would require. But one virtue of the substantive-norms reading is that it brings to the surface the unfulfilled demand for substantive justification of diminished rights protection: It openly asserts that immigrants get lower levels of constitutional protection in various ways because that is all they deserve, and thereby arguably presses the courts either persuasively to justify the lower levels of protection, or to raise them.

The underenforced-norms thesis, in contrast, may have the effect of releasing that pressure on the courts without improving immigrants' constitutional rights protection. As a practical matter, the underenforced-norms thesis points to the political branches as the place where the constitutional buck stops. But, as we have acknowledged, the political branches may be ill-suited and unlikely to act against their own turf interests to fully enforce immigrants' individual rights. The net result might well be a stronger normative justification for judicial abdication, accompanied by a precatory, unenforceable, and unheeded obligation on Congress and the executive.

The risk that judicial deference leads to unjustified incursions into individual rights provides additional reason for courts to curtail that deference and to fully enforce constitutional norms. We have outlined two parallel and distinct theories of Miller: First, we argue that, given the underenforced constitutional norms reading of the plenary power cases, the political branches themselves should have fully enforced constitutional sex discrimination norms when they amended Section 309(a); second, we argue that the Court's decision in Miller points the way to full judicial enforcement of constitutional norms for citizenship and immigration matters alike. If one concludes that constitutional enforcement of individual rights by the political branches against their own institutional habits and interests is an awkward and unlikely proposition, then full enforcement by the judiciary seems more attractive. Faced with a clear constitutional norm that overbroad sex-based classifications are unconstitutional in the absence of an "exceed- 
ingly persuasive" governmental justification, ${ }^{228}$ Congress in 1986 added and the President approved new sex-based classifications in the INA even though sex-neutral provisions would have worked as well. There is no evidence that the political branches played the role the underenforced-norms theory gives them. The 1986 amendments to Section 309(a) illustrate the risk that, if courts do not enforce the constitutional rights of people like the Millers, nobody will.

B. GOVERNMENT LAWYERING UNDER FULLY ENFORCED NORMS: SECTION 309(A) AND IMMIGRATION LAW

The preceding discussion addresses some consequences for government lawyering of the underenforced-norms thesis. But we argued in Part III that the judiciary, in light of Miller, has bases for fully enforcing constitutional norms in immigration, nationality, and citizenship. The prospect of full enforcement raises new issues for government lawyers. There likely is another U.S. serviceman who has a child born overseas to a noncitizen mother. Suppose that serviceman seeks to challenge the constitutionality of the statute left standing-barely-in Miller. What position should government lawyers and policy-makers take in such a case?

If the case reached a court, it would not be inappropriate for the government to argue that Miller did not hold Section 309 unconstitutional-Justice O'Connor's strong intimation is properly classified as dicta. But it would be inappropriate-in the postMiller world-for the government to trot out the plenary power cases and argue for extreme deference. Miller suggests that the usual norms of constitutional law will apply, at the very least, to jus sanguinis citizenship cases. Thus the government must decide what its substantive position is on the question of the explicit sexbased rule in the statute. Once Justice Frankfurter's crutch of deference is gone, what would be the government's reason for asserting that its successful argument in United States $v$ Virginia for significantly heightened scrutiny should not apply in citizenship cases? Of course, the government would be free to argue, as it did in Miller, that the statute satisfies heightened scrutiny. But it seems

${ }^{228}$ Hogan, 458 US at 725. 
clear that a majority of the Justices rejected that view-and rightly so, according to our earlier analysis.

Because the logic of Miller is not limited to jus sanguinis statutes, the requirement that a government advocate present a substantive theory of government power justifying diminished scrutiny ought also to apply in immigration cases. Assume, for example, a legal challenge to provisions in the immigration code that permit parents of U.S. citizens to obtain immigrant status in the United States but do not provide similar benefits to parents of resident aliens. ${ }^{229}$ Even conceding a new era of full enforcement, the government might well wish to argue for a low level of judicial scrutiny. Such an argument could be based on the substantive claim that distinctions between citizens and aliens are constitutionally tolerable. But the theoretical architecture of such an argument could not be based on the quasi-political question foundation of the plenary power cases; rather, the government would have to come forward with a plausible constitutional account of why norms of equal protection do not condemn this instance of discrimination based on alienage. 230

Government legal advisers are in a slightly different position. Their duty is not to try to defend an existing, duly enacted statute, regulation, or other governmental act. Rather, their job is to inform the client of the legality of planned conduct under their best view of the prevailing law. (Of course, this might include a judgment of where the law is likely to go and how the government might edge it along in that direction.)

Consider, then, how the State Department ought to treat the next application for registration as a U.S. citizen by a person in Lorelyn Miller's situation. The conscientious government adviser ought to read Miller $v$ Albright as giving last rites to the statutory provision. That reading, coupled with the government's position in Virginia, ought to lead the conscientious adviser to conclude that the statute cannot constitutionally be applied to deny citizenship to the applicant.

\footnotetext{
${ }^{229}$ See INA $\$ 201(\mathrm{~b}), 8$ USC $\$ 1151(\mathrm{~b})$.

${ }^{230}$ Once shorn of the old plenary power language, the justifications become remarkably thin. See John W. Guendelsberger, The Right to Family Unification in French and United States Immigration Law, 21 Cornell Intl L J 1 (1988); T. Alexander Aleinikoff, The Tigbtening Circle of Membersbip, 22 Hastings Const L Q 915, 921-22 (1995).
} 
But that is only half a solution. It tells the State Department that it cannot deny citizenship in such a case, but it does not demonstrate that the applicant must be granted citizenship. The question is whether-and if so, how-the offending provision might be severed from the other provisions regulating jus sanguinis citizenship. At first blush it might be suggested that the State Department simply treat Section 309 as a nullity, thereby permitting the out-of-wedlock applicant to be recognized as a citizen under Section $301(\mathrm{~g})$ if the U.S. citizen father had met the statutory U.S. residency requirements. But, as we explore in the paragraphs that follow, the statutory structure is complicated enough to give a conscientious government decision maker pause before simply registering the applicant as a citizen.

First recall the rules for children born in wedlock to a U.S. citizen parent and a noncitizen parent. Under INA Section 301(g), such children are citizens at birth provided that the U.S. citizen parent had been "physically present in the United States ... for a period or periods totaling not less than five years, at least two of which were after attaining the age of fourteen years." ${ }^{231}$ The rules for children born out of wedlock, defined in INA Section 309, are different for children of U.S. citizen mothers as compared to children of U.S. citizen fathers. (This, of course, was the issue in Miller.) Out-of-wedlock children of U.S. citizen mothers obtain citizenship at birth if the mother has "previously been physically present in the United States . . f for a continuous period of one year." ${ }^{332}$ The rules for nonmarital children born to U.S. citizen fathers were what was under scrutiny in Miller-requiring five years' U.S. residency plus a special showing regarding paternal ties.

Thus the residency requirements for out-of-wedlock children born to a U.S. parent are importantly different from the standards applied to children born in wedlock to a U.S. citizen parent and a noncitizen parent-and different in a somewhat peculiar way. Compared to the five-year residency requirements for parents of in-wedlock children, out-of-wedlock children born abroad to U.S. citizen fathers face tougher rules: they must meet the five-year parent-residency rule of Section 301(g) as well as the special rules of Section 309(a). But nonmarital children born to U.S. citizen moth-

\footnotetext{
${ }^{231}$ INA $\$ 309(\mathrm{~g})$, USC $\$ 1401(\mathrm{~g})$

${ }^{232}$ INA $\S 309(\mathrm{c}), 8$ USC $\$ 1409(\mathrm{c})$.
} 
ers face easier rules: They obtain citizenship at birth if their mother was physically present in the United States for one year prior to their birth. ${ }^{233}$

It is thus far from clear exactly how the conscientious policymaker at the State Department ought to proceed in ensuring sex equality under the statute. Justice Breyer's dissent proposes that the government simply treat the offending provisions as nullities, effectively deleting the support and legitimation/acknowledgment elements of Section 309(a) from the code. ${ }^{234}$ But this approach would leave in place Section 309(c), which establishes the more favorable residency rule for U.S. citizen mothers of nonmarital children. ${ }^{235}$ It thus does not render the statute sex-neutral. ${ }^{236}$

Another alternative would be to consider Section 309 a nullity in its entirety. Out-of-wedlock children would thereby be able to obtain citizenship directly under Section 301's requirements. But this solution produces the curious result of adopting a less favorable rule for out-of-wedlock children born to U.S. citizen mothers than is currently the case (i.e., mothers of these children would now have to have resided in the United States for five years rather than the current requirement of one year). This may be a sensible result-the current favorable treatment may be a relic of the past. $^{237}$ But it is not clear that the State Department has the authority to deny citizenship to a class of persons currently entitled to citizenship under federal statutes. ${ }^{238}$ Moreover, for more than

\footnotetext{
${ }^{233}$ As noted earlier (note 14), the favorable treatment accorded nonmarital children of U.S. citizen mothers was motivated primarily by a desire to avoid statelessness. Because the citizenship of a nonmarital child usually followed the citizenship of the mother, a child of a U.S. citizen mother and a noncitizen father born in the father's home country was likely to be stateless unless the child was recognized as a U.S. citizen. Accordingly, U.S. law adopted a relaxed standard for nonmarital children born to U.S. mothers abroad. Nonmarital children of U.S. citizen fathers did not usually require special treatment in order to be a citizen somewhere: They likely acquired the citizenship of the non-U.S. mother at birth. See Wauchope v U.S. Dep't of State, 985 F2d at 1414.

${ }^{234} 118 \mathrm{~S} \mathrm{Ct}$ at 1463-64 (Breyer dissenting).

${ }^{235}$ 'Thus we are mystified-as was Justice Breyer-by Justice Scalia's assertion that Justice Breyer's remedy would favor fathers over mothers. See id at 1449 (Scalia concurring); 1464 (Breyer dissenting).

${ }^{236}$ As noted, such favorable treatment of mothers was originally justified on grounds of avoiding statelessness. But there is no reason that such a provision cannot be sex-neutral.

${ }^{237}$ See note 171. But see Br for Resp 33-34 n 18, reporting the views of the State Department that concern about statelessness are still applicable to out-of-wedlock children born to U.S. citizen mothers in Germany, Great Britain, South Korea, and Vietnam.

${ }^{238}$ Compare Califano $v$ Westcott, 443 US 76, 92 (1979) (rejecting state's proposed sexneutral remedy for unconstitutional sex discrimination in a welfare statute that would have
} 
fifty years Congress has had separate jus sanguinis rules for outof-wedlock and in-wedlock children. Eliminating that difference might be a good thing. But it seems likely that Congress would seek to maintain it in some form, albeit with sex-neutral categories. ${ }^{239}$ Thus, if the goal of the conscientious decision maker is to devise a sex-neutral policy consistent with the intent and structure of the underlying statute, treating Section 309 as a nullity appears to be an inappropriate response.

Another strategy would be to try to render Section 309 (governing nonmarital children) sex-neutral, either by (1) applying the rules for mothers to fathers, (2) applying the rules for fathers to mothers, or (3) crafting a new set of rules that would apply to both (e.g., a rule that would grant citizenship where the U.S. citizen could demonstrate a caretaker parent role). The last alternativewhich appears sensible to us-seems consistent both with congressional intent (assuming that the invalid sex-based rule was based on concern about the existence of a parent-child relationship) and with the structure of the statute (by maintaining different rules for out-of-wedlock and in-wedlock children). But, as with the strategy of simply treating Section 309 as a nullity, a new rule such as this would deny citizenship to some children who are currently granted citizenship by the current statute-that is, out-of-wedlock children of U.S. mothers whose mother cannot meet the new standard. If the executive concludes that this is a result Congress would wish to avoid, then it rules out both this alternative and the second alternative of applying the rule for fathers to mothers.

We are therefore left with the first alternative of applying the rule for mothers in Section 309(c) to fathers. But this would produce the curious result of treating the out-of-wedlock children of one U.S. citizen parent and one noncitizen parent more favorably than the in-wedlock children born to a similarly mixed-citizenship couple: The father of an out-of-wedlock child would have to establish U.S. residency of only a year (under a sex-neutral Section

had the effect of terminating eligibility for benefits of some families currently receiving them).

${ }^{239}$ Differential treatment might be based on the perception that parents are less likely to have close relationships with out-of-wedlock children. We express no view on the constitutionality of such an assumption in a post-Miller world, for example, under constitutional decisions prohibiting discrimination based on illegitimacy-but it would behoove the government to assess its constitutionality before adopting a policy based on sucb an assumption. 
309(c)), while the father of an in-wedlock child would have to establish U.S. residency of five years (under Section 301(g)). Furthermore, the rule would require no showing of any established parent-child relationship, a result that seems distinctly contrary to congressional intent.

In the somewhat analogous situation of a court attempting to remedy the unconstitutionality of an underinclusive statute, the Supreme Court has stated that the judge must "measure the intensity of [Congress's] commitment to the residual policy and consider the degree of potential disruption of the statutory scheme that would occur by extension as opposed to abrogation." ${ }^{240}$ Under this analysis, the Department of State has no good option. Congress's commitment to the "residual policy" of wanting assurance of a parent-child relationship in the case of out-of-wedlock children appears strong; and the crafting of sex-neutral rules, either by extending the treatment afforded U.S. citizen mothers to U.S. citizen fathers or by abrogating Section 309 altogether, seems to disrupt significantly the statutory scheme. So the Department of State faces a real quandary: Denying recognition of the citizenship of our hypothetical applicant would be an unconstitutional act; but there is no obvious way to anticipate how Congress would choose among the various feasible sex-neutral rules for recognition of citizenship. What, then, should the conscientious policy-maker do?

The overriding duty of the State Department is to act in conformity with the Constitution. Thus, it may not deny citizenship to our hypothetical applicant on the basis of INA Section 309(a). Beyond this, the answer remains unclear. Any plausible rule that the Department might craft to overcome the constitutional problem would appear either to deny citizenship to persons who would be eligible for it under the current statute or to entitle persons to citizenship in a manner inconsistent with congressional intent. The State Department could, we suppose, do its best at guessing how Congress would have answered the question if it had known that the current rules were unconstitutional. But given the complexity of the materials here, such a guess would have all the appearance of a coin toss. In such a case, we believe the wisest course of action is for the State Department (1) not to deny citizenship to

\footnotetext{
${ }^{240}$ Heckler v Mathews, 465 US 728, 739 n 5 (1984), quoting Welsh v United States, 398 US 333, 365 (1970) (Harlan concurring).
} 
out-of-wedlock children of U.S. citizen fathers, and (2) to propose legislation that remedies the unconstitutionality of the present statute. $^{241}$

\section{Conclusion}

But for want of the proper plaintiff, one of the few remaining sex-based distinctions in immigration and nationality law would be history. Unfortunately, the Court's recognition that fully enforced norms apply in citizenship cases came without the help of the Solicitor General-indeed, in the face of a brief that argued not only that Lorelyn Miller had no rights to assert but further that, even if she did, the law passed constitutional muster under the heightened scrutiny test applied to sex-based statutes. Neither position of the government is tenable, and a majority of the Justices properly rejected both.

Under our reading of the plenary power doctrine, of course, the issue never should have reached the Court. Institutionally based judicial deference to the political branches places the responsibility with Congress and the executive to apply full-fledged constitutional norms even when the courts will not. If the political branches had been doing their part, they would have amended the INA provisions governing jus sanguinis citizenship for nonmarital children born abroad of mixed-citizenship parentage to make them sex-neutral. The political branches instead have treated the plenary power doctrine like a blank check, leaving them free to do whatever the courts will allow. But Miller suggests that, where the political branches abdicate, the courts may now step in.

${ }^{241}$ There is a precedent for doing just that. One exanple occurred in case that is a close cousin to Miller. Wauchope v U.S. Dep't of State, 985 F2d 1407 (9th Cir 1993), considered a constitutional challenge to earlier jus sanguinis rules that had permitted U.S. citizen fathers but not mothers to pass citizenship by descent. Although the law was made sex-neutral in 1934 , its discriminatory effects lingered because the statutory changes were not made retroactive. Thus, cbildren born overseas to U.S. citizen mothers before 1934 were not recognized as citizens at birth. The court of appeals upheld the lower court's finding of an equal protection violation, and it rejected the government's argument that the district court erred in declaring the plaintiffs U.S. citizens. The United States decided not to appeal, based on the conclusion that the Ninth Circuit's ruling was consistent with modern-day sex discrimination norms. Instead, it proposed legislation, subsequently adopted by Congress, that retrospectively remedied the sex-based inequality. Immigration and Nationality Technical Corrections Act of 1994, $\$ 1$, Pub L 103-416, 108 Stat 4305, 4306. See Drew S. Days III, The Solicitor General and the American Legal Ideal, 49 SMU L Rev 73, 81 (1995). 
Miller does more than cast doubt on sex-based citizenship laws. It forces fundamental reconsideration of the underpinnings of the plenary power doctrine. This means that the government is no longer entitled to argue for extreme judicial deference in immigration and nationality cases; rather, it must come up with a substantive constitutional theory regarding the extent of and limits upon the federal immigration power. That theory, to be consistent with Miller and true to the government's position in United States $v$ Virginia, should begin with the premise that sex-based rules in immigration and nationality laws are presumptively unconstitutional.

Miller $v$ Albright is a case with the wrong plaintiff seeking relief that cannot easily be granted by a court or the executive branch. Yet sometimes hard cases make good law. 